\title{
Aminoglycoside-Induced Phosphatidylserine Externalization in Sensory Hair Cells Is Regionally Restricted, Rapid, and Reversible
}

\author{
Richard J. Goodyear, ${ }^{1 *}$ Jonathan E. Gale, ${ }^{2,3 *}$ Kishani M. Ranatunga, ${ }^{1}$ Corné J. Kros, ${ }^{1}$ and Guy P. Richardson ${ }^{1}$ \\ ${ }^{1}$ School of Life Sciences, University of Sussex, Brighton BN1 9QG, United Kingdom, and ${ }^{2}$ UCL Ear Institute and ${ }^{3}$ Department of Physiology, University \\ College London, London WC1X 8EE, United Kingdom
}

The aminophospholipid phosphatidylserine (PS) is normally restricted to the inner leaflet of the plasma membrane. During certain cellular processes, including apoptosis, PS translocates to the outer leaflet and can be labeled with externally applied annexin V, a calcium-dependent PS-binding protein. In mouse cochlear cultures, annexin V labeling reveals that the aminoglycoside antibiotic neomycin induces rapid PS externalization, specifically on the apical surface of hair cells. PS externalization is observed within $\sim 75 \mathrm{~s}$ of neomycin perfusion, first on the hair bundle and then on membrane blebs forming around the apical surface. Whole-cell capacitance also increases significantly within minutes of neomycin application, indicating that blebbing is accompanied by membrane addition to the hair cell surface. PS externalization and membrane blebbing can, nonetheless, occur independently. Pretreating hair cells with calcium chelators, a procedure that blocks mechanotransduction, or overexpressing a phosphatidylinositol 4,5-biphosphate (PIP2)-binding pleckstrin homology domain, can reduce neomycin-induced PS externalization, suggesting that neomycin enters hair cells via transduction channels, clusters PIP2, and thereby activates lipid scrambling. The effects of short-term neomycin treatment are reversible. After neomycin washout, PS is no longer detected on the apical surface, apical membrane blebs disappear, and surface-bound annexin V is internalized, distributing throughout the supranuclear cytoplasm of the hair cell. Hair cells can therefore repair, and recover from, neomycin-induced surface damage. Hair cells lacking myosin VI, a minus-end directed actin-based motor implicated in endocytosis, can also recover from brief neomycin treatment. Internalized annexin $\mathrm{V}$, however, remains below the apical surface, thereby pinpointing a critical role for myosin VI in the transport of endocytosed material away from the periphery of the hair cell.

Key words: hair cell; phosphatidylserine; annexin V; aminoglycoside; FM1-43; myosin VI

\section{Introduction}

Sensory hair cells of the inner ear are polarized epithelial cells. They have an apical mechanosensory hair bundle that is composed of numerous actin-packed stereocilia and, in all organs but the mature cochlea, a single kinocilium. The maintenance of hair bundle structure is critical for normal hearing and balance (for review, see Frolenkov et al., 2004; Petit, 2006), and recent studies have shown that components of the stereocilia and their ensheathing plasma membranes undergo continual turnover and renewal (Schneider et al., 2002; Grati et al., 2006).

In the early-postnatal mouse cochlea and bullfrog saccule, numerous coated pits are associated with the apical membrane of hair cells, and smooth vesicles of varying diameter are abundant in the cytoplasm surrounding the cuticular plate, a dense cy-

\footnotetext{
Received March 14, 2008; revised July 23, 2008; accepted Aug. 16, 2008

This work was supported by The Wellcome Trust (G.P.R., R.J.G.), the Medical Research Council (K.M.R., C.J.K.), a Royal Society University Research Fellowship (J.E.G.), and a grant from The Wolfson Foundation for imaging equipment at the University College London Ear Institute. We thank Manuela Lahne for her helpful suggestions. ${ }^{*}$ R.J.G. and J.E.G. contributed equally to this work.

Correspondence should be addressed to Dr. Guy P. Richardson, School of Life Sciences, University of Sussex, Falmer, Brighton BN1 90G, UK. E-mail: g.p.richardson@sussex.ac.uk. D0I:10.1523/JNEUROSCI.1124-08.2008

Copyright $\odot 2008$ Society for Neuroscience $\quad 0270-6474 / 08 / 289939-14 \$ 15.00 / 0$
}

toskeletal meshwork that lies just below the hair bundle (Forge and Richardson, 1993; Hasson et al., 1997; Kachar et al., 1997). When explants of the early-postnatal mouse cochlea are exposed to the ototoxic aminoglycoside antibiotic neomycin, numerous blebs form on the apical surface of each hair cell (Richardson and Russell, 1991). Many of these blebs are filled with whorls of membrane that is atypical: it is devoid of intramembrane particles and cholesterol-free, and fractures in a manner that is suggestive of a high content of unsaturated phospholipid in fluid phase (Forge and Richardson, 1993). Neomycin-induced blebs were suggested to result from an imbalance in the rates of membrane export to, and retrieval from, the apical membrane of the hair cell (Richardson and Russell, 1991; Forge and Richardson, 1993).

In the acutely isolated guinea pig organ of Corti, large lipid bubbles form at the apex of hair cells as a consequence of sodium loading. Furthermore, phosphatidylserine (PS), an aminophospholipid that is normally restricted to the inner face of the plasma membrane, can be detected in the outer leaflet of the apical membrane of the hair cells in these preparations with fluorescent annexin V, a calcium-dependent PS-binding protein. Although PS becomes exposed on the outer surface of most cells during cell death, these hair cells from the mature guinea pig inner ear do not show other signs of apoptosis (Shi et al., 2005). 
In untreated mouse cochlear cultures, PS cannot be detected in the outer leaflet of the apical membrane of the hair cell with annexin V. Neomycin treatment, however, causes rapid PS externalization, first on the hair bundle and then on blebs that form around the perimeter of the apex of the hair cell. Bleb formation correlates with a large increase in whole-cell capacitance, indicating neomycin also causes an increase in the area of the plasma membrane of the hair cell. Hair cells can recover from limited, neomycin-induced damage: bleb formation is reversible, PS asymmetry is restored, and surface-bound annexin $\mathrm{V}$ is internalized after neomycin washout. Recovery from neomycin-induced damage also occurs in hair cells that lack myosin VI, a molecular motor previously implicated in several aspects of endocytosis in polarized epithelial cells (Hasson, 2003; Buss et al., 2004). The trafficking of internalized annexin $\mathrm{V}$ within the hair cells of myosin VI-deficient mice is, however, found to be impaired.

\section{Materials and Methods}

Preparation of cochlear cultures. Cochlear cultures were prepared from wild-type CD-1 mice and Snell's waltzer (myosin VI mutant) mice as described previously (Russell and Richardson, 1987). Briefly, cochleae were obtained from 1- to 3-d-old pups and grown on collagen-coated round glass coverslips for $1-2 \mathrm{~d}$ at $37^{\circ} \mathrm{C}$ in Maximow slide assemblies using a medium containing 93\% DMEM/F12, 7\% fetal bovine serum, and $10 \mu \mathrm{g} \cdot \mathrm{ml}^{-1}$ ampicillin. Cochlear coils were divided into apical and basal segments during dissection and each coverslip that was set up contained two apical and two basal cochlear coils. Snell's waltzer pups were obtained from breeding pairs composed of homozygous males and heterozygous females and the resultant cultures were phenotyped on the basis of hair bundle morphology before use.

Live cell imaging. Coverslips with adherent cochlear cultures were transferred from the Maximow slide assemblies into a glass-bottom, Perspex slide chamber and $0.5 \mathrm{ml}$ of HEPES-buffered (10 mM), $\mathrm{pH} 7.2$, HBSS (HBHBSS) was added. The slide chamber was mounted on the stage of a Zeiss AxioPlan II or a Zeiss LSM 510 Meta confocal microscope and cells were viewed with Nomarski interference contrast optics using a $63 \times$ water-immersion objective, numerical aperture (NA) 0.95.

To study PS externalization, Alexa Fluor 488 annexin V (Invitrogen) was added to a dilution of 1:100 or 1:50, and the cells were imaged before and after the addition of neomycin, usually to a final concentration of 1 $\mathrm{mm}$. For non-confocal analysis, cells were imaged in one of the basal-coil cochlear cultures before the addition of neomycin (or compound to be tested), and in each of the cochlear coils at fixed time points after addition of neomycin, usually collecting interference contrast and fluorescence images at 5, 10, and 15 min time points for the first basal coil; 6,11 , and 16 min for the second basal coil; 7, 12, and $17 \mathrm{~min}$ for the first apical coil; and 8,13 , and $18 \mathrm{~min}$ for the second apical coil. Exposure to illumination was kept to a minimum during the experiment and restricted to the times necessary to focus and capture the images. Images were taken from fields in the middle region of each coil with a Spot RT slider digital camera using fixed exposure times for the fluorescent images (usually 2 or $3 \mathrm{~s}$ ) and stored on a computer. When compounds were tested for their ability to block neomycin-induced PS externalization, they were added to the cultures for $20 \mathrm{~min}$ before the addition of neomycin and were present throughout the experiment. The following compounds were tested for their ability to elicit PS externalization and/or to block neomycin-induced PS externalization: the adenylate cyclase inhibitor 9-(tetrahydro-2-furanyl)9H-purin-6-amine (SQ22536), the phosphatidylinositol-3 (PI-3) kinase inhibitor 2-(4-morpholinyl)-8-phenyl-4 H-1-benzopyran-4-one (LY294002) (Calbiochem), the membrane transport inhibitor brefeldin $\mathrm{A}$, the $\mathrm{Na}^{+} \mathrm{K}^{+}$ ATPase inhibitor ouabain, the calcium ionophores ionomycin and 5-methylamino-2-[[(2S,3R,5R,8S,9S)-3,5,9-trimethyl-2-[1-oxo-1(1 Hpyrrol-2-yl)propan-2-yl]-1,7-dioxaspiro[5.5] undecan-8-yl]methyl]benzoxazole-4-carboxylic acid (A23187), poly-L-lysine, and the adenylate cyclase agonists forskolin and 6-acetyl-7-deacetylforskolin. Other compounds tested for their ability to elicit PS externalization were spermine, poly-Llysine, cisplatin, and the aminoglycoside antibiotics gentamicin and dihy- drostreptomycin (unless stated otherwise, chemicals were from SigmaAldrich). To test the effects of calcium chelation on PS externalization, cultures were incubated at room temperature in nominally $\mathrm{Ca}^{2+}$-free $\mathrm{HB}-$ HBSS containing $5 \mathrm{~mm}$ EGTA for $15 \mathrm{~min}$, washed three times in HBHBSS, incubated for an additional $45 \mathrm{~min}$ in HBHBSS, and then exposed to neomycin in the presence of Alexa Fluor 488 annexin $\mathrm{V}$ as described above.

For live confocal analysis, cells were imaged using either a Zeiss LSM 510 Meta Axioskop upright confocal microscope and a $63 \times$ waterimmersion objective (NA, 1.0) or with a Nipkow spinning disk scanhead (Ultraview ERS; PerkinElmer) attached to a Zeiss Axiovert 200 inverted microscope maintained in an incubation chamber (Solent Scientific). For the latter, the $488 \mathrm{~nm}$ line of a $\mathrm{Kr}$-Ar laser (Melles Griot) was used to excite Alexa Fluor 488 and a piezo-actuator (Piezosystem Jena) used to control the $Z$ position of the objective lens. Epifluorescence images were collected through an LP $505 \mathrm{~nm}$ filter onto an Orca-ER cooled CCD camera (Hamamatsu) using 20 or $63 \times$ objectives. The incubator maintained the preparation at $37^{\circ} \mathrm{C}$.

Images were acquired with the LSM 510 Meta using the 488 and 633 nm laser lines to excite Alexa Fluor 488 and Alexa Fluor 647 annexin V, respectively. Because of the broad emission spectrum of FM1-43, separation of green fluorescence protein (GFP) from FM1-43 fluorescence and Alexa Fluor 647 from FM1-43 florescence was required. This was obtained by the acquisition of lambda stacks (multichannel emission acquisition using the Zeiss Meta system) to obtain the spectral profile of the fluorescence signals to which the linear unmixing algorithms in the LSM software (Zeiss) were applied. Alternatively, the images were extracted from the appropriate peak emission channel (10 $\mathrm{nm}$ bandwidth) (e.g., $570 \mathrm{~nm}$ for FM1-43 and $667 \mathrm{~nm}$ for Alexa Fluor 647). For live confocal imaging, laser intensities were kept to the minimum required to obtain an image to minimize photobleaching and phototoxicity.

Calcium imaging. Wide-field calcium imaging was performed as described previously (Gale et al., 2004). Briefly, fura-2 (6 $\mu \mathrm{M})$ was loaded into cochlear cultures using the AM ester form. The dye was excited at 340 and $380 \mathrm{~nm}$ using a monochromator-based imaging system coupled to a cooled CCD camera under software control (Andor Imaging). For confocal calcium imaging, Oregon Green BAPTA-488 (12 $\mu \mathrm{M})$ was loaded into cultures using the AM ester form and the dye was excited using the $488 \mathrm{~nm}$ line of the Zeiss LSM 510 Meta Axioskop upright confocal microscope. Applications of $20 \mathrm{mM} \mathrm{Ca}^{2+}, 100 \mu \mathrm{M}$ ATP, and 10 $\mu \mathrm{M}$ ionomycin were made via local perfusion with a micropipette, and confocal optical slices were acquired at intervals of $\sim 2 \mathrm{~s}$.

Capacitance recordings. Cochlear cultures were continually perfused with the following extracellular recording solution (in mM): $135 \mathrm{NaCl}$, $5.8 \mathrm{KCl}, 1.3 \mathrm{CaCl}_{2}, 0.9 \mathrm{MgCl}_{2}, 0.7 \mathrm{NaH}_{2} \mathrm{PO}_{4}, 5.6$ D-glucose, 10 HEPES$\mathrm{NaOH}, 2$ sodium pyruvate, amino acids and vitamins for Eagle's MEM added from concentrates (Invitrogen), $\mathrm{pH} 7.48$ and $308 \mathrm{mOsm} \cdot \mathrm{kg}^{-1}$. A small tear was made in the epithelium with a suction pipette (tip diameter, $\sim 5 \mu \mathrm{m}$ ) to expose the basolateral surface of the cell for access with the patch pipette.

The whole-cell capacitance was derived from the transient response of the membrane current stepped from a holding potential of $-84 \mathrm{mV}$ (including the liquid junction potential of $-4 \mathrm{mV}$ ) to $-94 \mathrm{mV}$ for $5 \mathrm{~ms}$. Currents were recorded from third row outer hair cells in either the basal part of apical coils or the basal coils using the whole-cell patch-clamp technique. The intracellular solution consisted of the following (in $\mathrm{mm}$ ): $131 \mathrm{KCl}, 3 \mathrm{MgCl}_{2}, 1$ EGTA-KOH, $5 \mathrm{Na}_{2} \mathrm{ATP}, 10$ sodium phosphocreatine, 5 HEPES-KOH, pH 7.28 and $295 \mathrm{mOsm} \cdot \mathrm{kg}^{-1}$. Data were sampled at $100 \mathrm{kHz}$ and low-pass filtered at $20 \mathrm{kHz}$. A $100 \mathrm{~mm}$ neomycin stock was made up daily in extracellular solution. Neomycin (1 mM) was extracellularly superfused from a gravity-fed multibarrelled pipette positioned close to the preparation.

Immunogold electron microscopy. Cochlear cultures were transferred into 35-mm-diameter plastic Petri dishes, $1.0 \mathrm{ml}$ of HBHBSS was added, and Alexa Fluor 488 annexin V was added to a dilution of 1:100. Neomycin (from a stock solution of $100 \mathrm{~mm}$ ) was added to a final concentration of $1 \mathrm{~mm}$, and the cultures were incubated for an additional $10 \mathrm{~min}$. As a control, an equal volume of saline was added. After a brief wash with $3 \mathrm{ml}$ of HBHBSS, cultures were fixed in $4 \%$ paraformaldehyde in $0.1 \mathrm{~m}$ sodium phosphate buffer for $1 \mathrm{~h}$, washed three times with PBS, preblocked in 

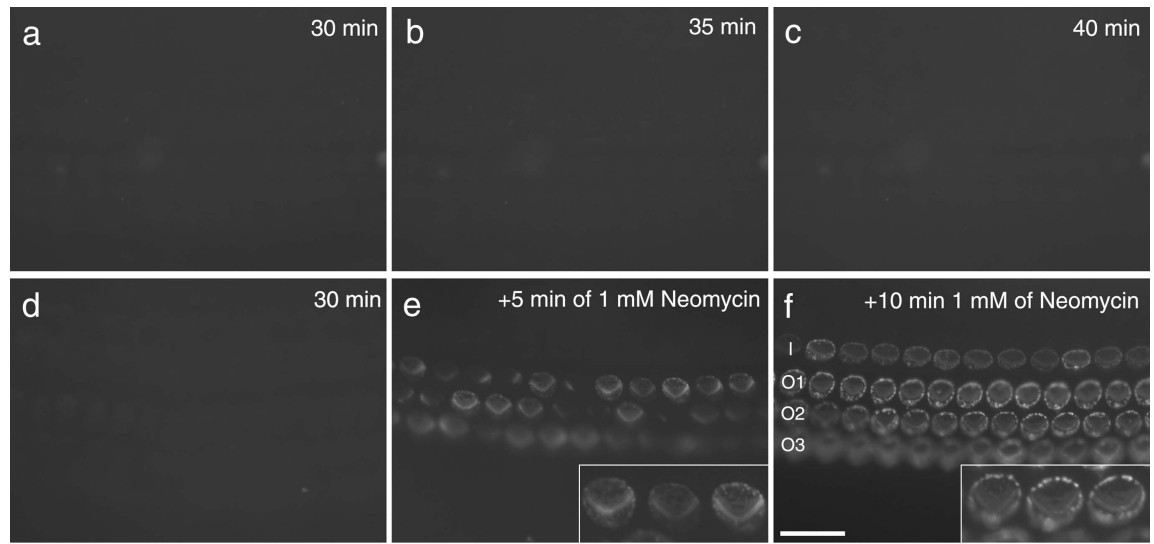

Figure 1. Annexin V labels the hair cell apical surface after neomycin treatment. $\boldsymbol{a}-\boldsymbol{f}$, Wide-field fluorescence micrographs of basal-coil cochlear cultures. Culture in $\boldsymbol{a}$ - c was incubated in saline containing Alexa Fluor 488 annexin V for 30 min (a), 35 min (b) and $40 \mathrm{~min}$ (c). Culture in $\boldsymbol{d}-\boldsymbol{f}$ was incubated in saline containing Alexa Fluor 488 annexin V for $30 \mathrm{~min}$ (d). Neomycin was then added to a concentration of $1 \mathrm{~mm}$, and images were taken $5 \mathrm{~min}(\boldsymbol{e})$ and $10 \mathrm{~min}(\boldsymbol{f})$ later. Note the hair bundle labeling at $5 \mathrm{~min}$ after neomycin addition $(\boldsymbol{e})$, and strong staining around the perimeter of the hair cell apex by $10 \mathrm{~min}(\boldsymbol{f})$. I, Inner hair cell row; 01 , 02 , and 03 , outer hair cell rows 1, 2, and 3, respectively. Scale bar: (in $\boldsymbol{f}$ ) $\boldsymbol{a}-\boldsymbol{f}, 20 \mu \mathrm{m}$. The insets in $\boldsymbol{e}$ and $\boldsymbol{f}$ are $2 \times$ zooms of selected outer hair cells.

$10 \%$ heat-inactivated horse serum in TBS for $1 \mathrm{~h}$, and incubated overnight in preblock solution containing rabbit anti-Alexa Fluor $488 \mathrm{IgG}$ at a dilution of 1:100. Samples were washed five times with TBS, incubated for an additional $2 \mathrm{~h}$ in $5 \mathrm{~nm}$ gold-conjugated goat anti-rabbit IgG diluted 1:10 in TBS/HS containing 0.05\% Tween 20 and 1 mm EDTA, washed in TBS, and refixed in $2.5 \%$ glutaraldehyde followed by osmium tetroxide. Samples were finally dehydrated in ethanol, imbedded in Epon, and sectioned at a thickness of $100 \mathrm{~nm}$. Sections were stained with uranyl acetate and lead citrate and viewed with a Hitachi 7100 microscope operating at $100 \mathrm{kV}$. Images were captured with a Gatan Ultrascan 1000 CCD camera.

Scanning electron microscopy. Cultures were fixed in $2.5 \%$ glutaraldehyde in $0.1 \mathrm{~m}$ sodium cacodylate, $\mathrm{pH} 7.2$, for $1 \mathrm{~h}$, washed three times in $0.1 \mathrm{M}$ sodium cacodylate buffer, postfixed in $1 \%$ osmium tetroxide in 0.1 M sodium cacodylate buffer for $1 \mathrm{~h}$, washed two times in cacodylate buffer, once briefly in water, dehydrated through a series of ascending concentrations of ethanol and critical point dried from liquid $\mathrm{CO}_{2}$. Dried cultures were mounted on aluminum stubs with double-sided sticky tape, sputter coated with gold, and viewed with a Leica Leo S420 scanning electron microscope operating at $20 \mathrm{kV}$.

Biolistic transfection of cochlear cultures. Hair cells in cochlear cultures were transfected with a mammalian expression vector containing the $\mathrm{N}$-terminal pleckstrin homology domain of phospholipase $\mathrm{C} \delta 1$ ligated in frame with enhanced green fluorescent protein (EGFP) using a Helios gene gun as described previously (Phillips et al., 2006). After $20 \mathrm{~h}$, transfected cultures were transferred to $35-\mathrm{mm}$-diameter plastic Petri dishes with $1.0 \mathrm{ml}$ of HBHBSS, incubated for $5 \mathrm{~min}$ in Alexa Fluor 647 annexin $\mathrm{V}$ at a dilution of 1:100, treated with $1 \mathrm{~mm}$ neomycin for $10 \mathrm{~min}$, washed once briefly with HBHBSS, and fixed for $1 \mathrm{~h}$ in $4 \%$ paraformaldehyde in $0.1 \mathrm{M}$ sodium phosphate buffer, $\mathrm{pH}$ 7.4. After fixation, cultures were washed three times in PBS, preblocked and permeabilized in TBS/HS with $0.1 \%$ Triton X-100, and labeled with rabbit anti-GFP followed by FITC swine anti-rabbit and Texas Red phalloidin. Stained cultures were viewed with a LSM510 confocal microscope using a $100 \times$, NA 1.4 , oilimmersion lens.

Recovery protocols. To study the internalization of bound annexin $\mathrm{V}$ or recovery from neomycin-induced damage, cultures were washed once in HBHBSS, exposed to $1 \mathrm{~mm}$ neomycin in the presence or absence of Alexa Fluor 488 annexin $\mathrm{V}$ in HBHBSS for periods ranging from 5 to $30 \mathrm{~min}$ at ambient temperature, washed twice in HBHBSS and allowed to recover in culture medium (see above) at $37^{\circ} \mathrm{C}$ for up to $24 \mathrm{~h}$, or maintained in HBHBSS at room temperature for periods of up to $2 \mathrm{~h}$. Cultures were then washed with HBHBSS and labeled with annexin V (if not previously labeled) for confocal microscopy, or fixed for electron microscopy as described above.

Unless stated otherwise, experiments were performed at ambient temperature (usually 22$24^{\circ} \mathrm{C}$ ). Statistical comparisons were made by the paired Student's two-tailed $t$ test. Means \pm SEM are reported in text and figures. All procedures involving animals were performed according to Home Office regulations and with approval of the local ethical committee.

\section{Results}

\section{Neomycin induces the externalization} of phosphatidylserine

Labeling with fluorescent annexin $\mathrm{V}$ was used to detect the presence of PS in the external leaflet of the plasma membrane. In cochlear cultures that had been incubated in saline containing fluorescent annexin $\mathrm{V}$ for periods of up to $40 \mathrm{~min}$, cell surface labeling was not observed $($ Fig. $1 a-c)$. Shortly after the addition of $1 \mathrm{~mm}$ neomycin, however, labeling was seen of the hair bundles and in punctae located around the perimeter of the apical surface of the hair cell (Fig. 1d-f). Neomycin-induced annexin V labeling was evident in both inner and outer hair cells (Fig. $1 f$ ). It was not detected on hair cells from the apical end of cochlear cultures prepared from 1-d-old mice, but the degree to which labeling extended from the basal to the apical end of the cochlea increased as the developmental age of the animals used for making the cultures increased, presumably as a consequence of hair cell maturation. With cultures prepared from 3-d-old mice, annexin $V$ labeling was observed in response to neomycin treatment even in the most apically located hair cells (data not shown). The response to neomycin was time and dose dependent (supplemental Fig. 1, available at www.jneurosci.org as supplemental material).

To determine whether PS externalization was an effect common to all aminoglycoside antibiotics, gentamicin and dihydrostreptomycin were also tested. At a concentration of $1 \mathrm{~mm}$, both compounds caused annexin $\mathrm{V}$ labeling in a manner similar to that observed with neomycin (supplemental Fig. $2 a, b$, available at www.jneurosci.org as supplemental material). Spermine and poly-L-lysine cause bleb formation in hair cells of cochlear cultures (Kotecha and Richardson, 1994). Spermine at concentrations ranging from 0.5 to $10 \mathrm{~mm}$ did not elicit labeling, whereas poly-L-lysine at concentrations of 2 and $20 \mu \mathrm{M}$ elicited the formation of a small number of large, annexin $\mathrm{V}$-stained blebs on each hair cell (supplemental Fig. $2 c, d$, available at www.jneurosci.org as supplemental material). Brief exposure to the ototoxic anticancer drug cisplatin at a concentration of $1 \mathrm{~mm}$ did not cause annexin V labeling (supplemental Fig. 2e, available at www. jneurosci.org as supplemental material).

\section{Neomycin-induced PS externalization is restricted to the apical membrane of the hair cells}

Cultures were exposed to neomycin in the presence of Alexa Fluor 488 annexin V, fixed, and double labeled with Texas Red phalloidin to demarcate cell junctions. Confocal microscopy indicated that the annexin $\mathrm{V}$ labeling was restricted to the apical surface and not present on the basolateral membranes of the hair cells (Fig. $2 a, b)$ (see also Fig. $8 c, Z$ projections). Although neomycin-induced annexin $V$ labeling was restricted to the apical 

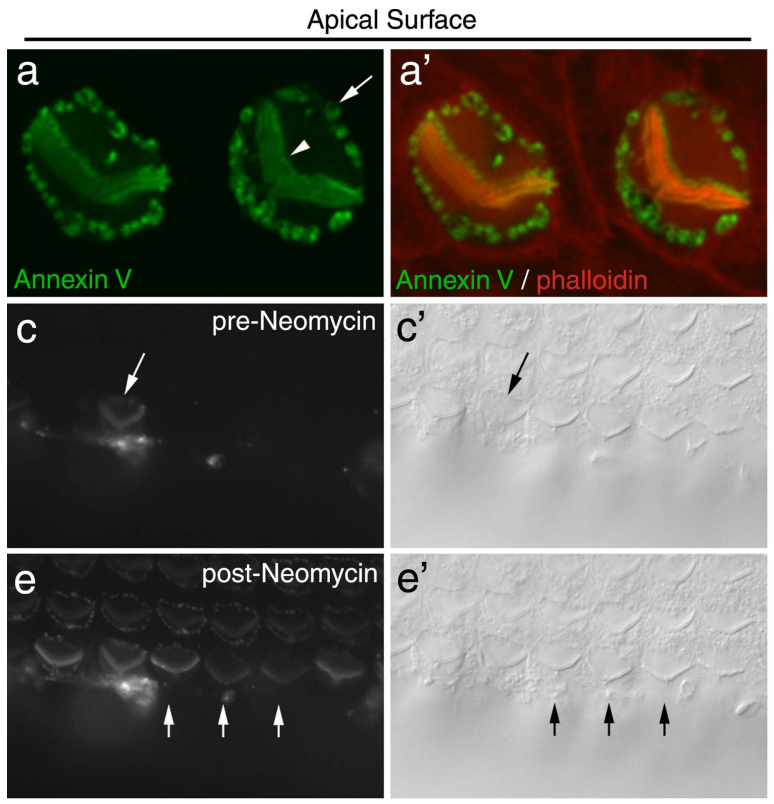

c'
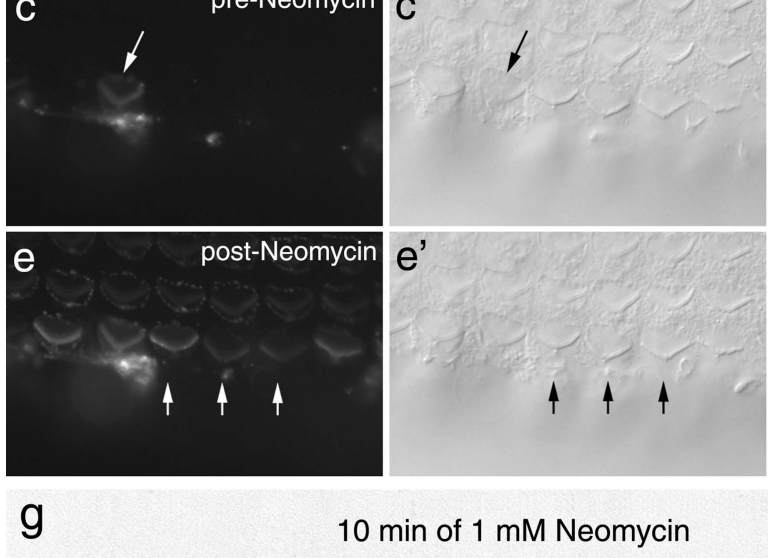

$$
\text { g }
$$

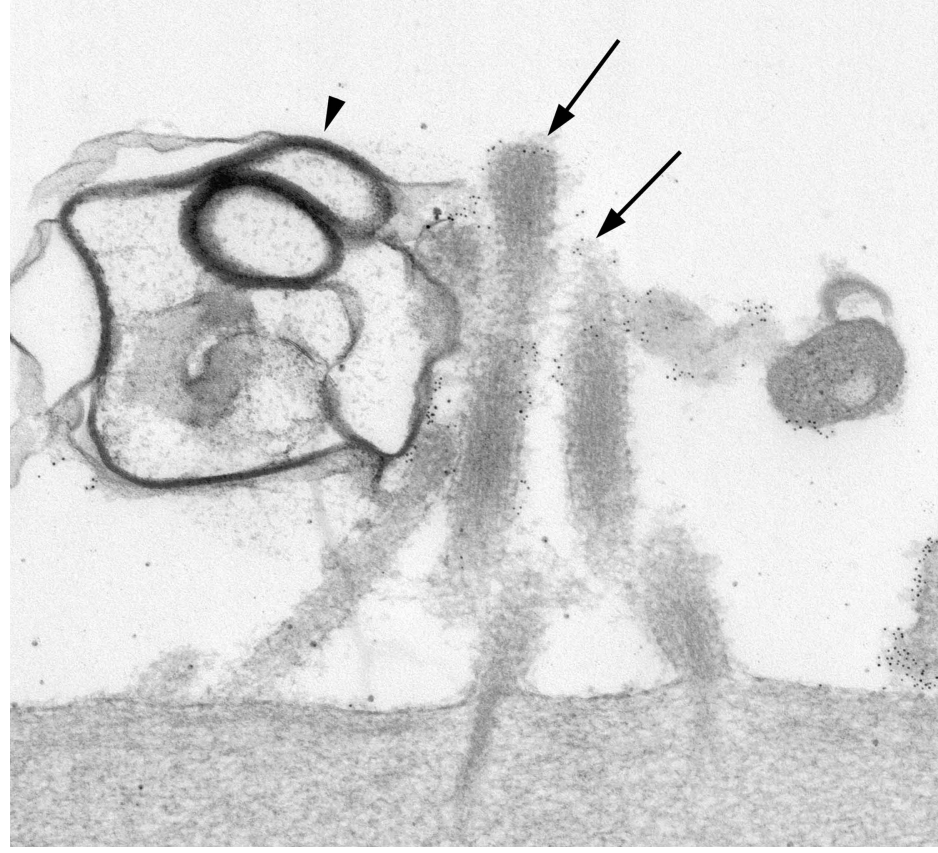

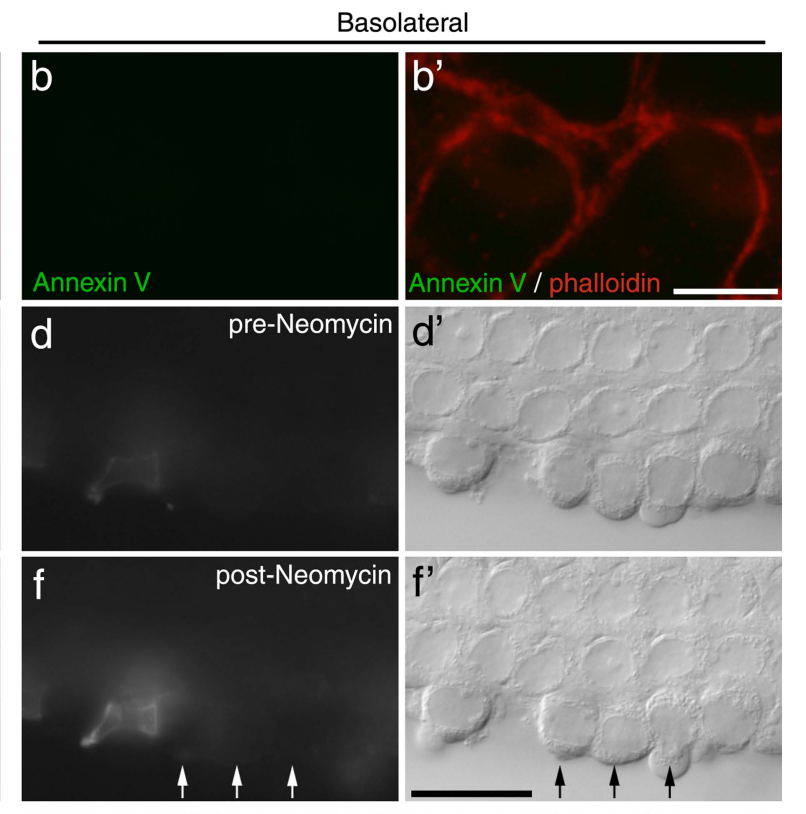
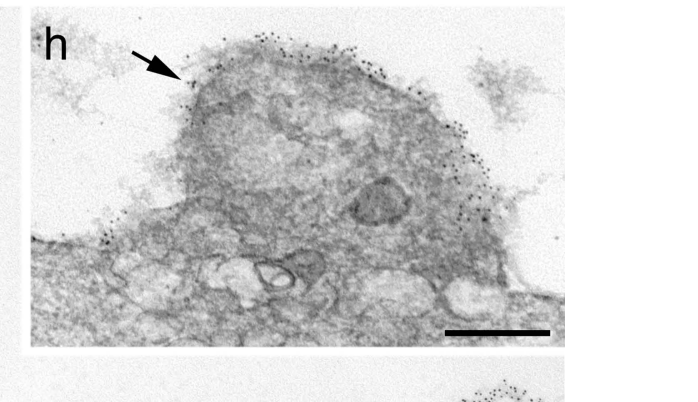


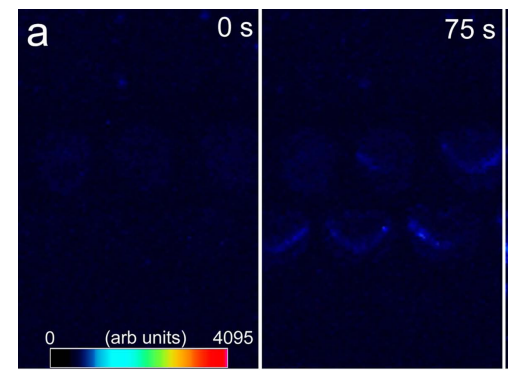

b

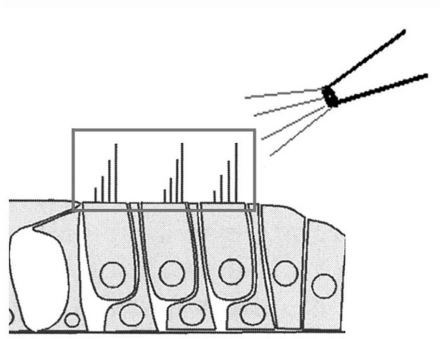

$\mathrm{C}$
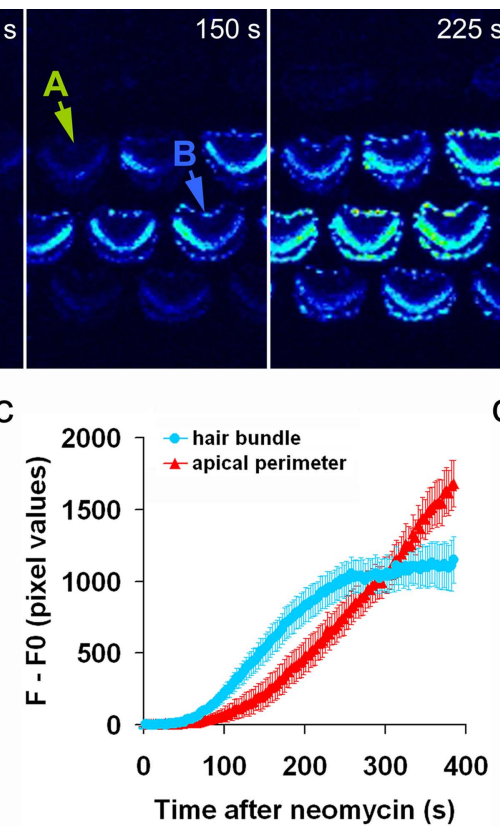
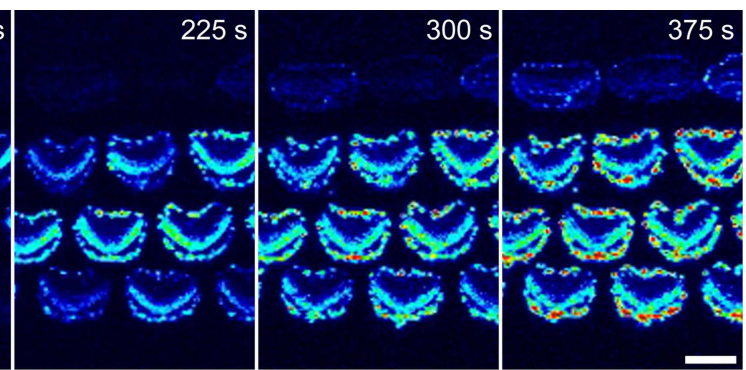

d

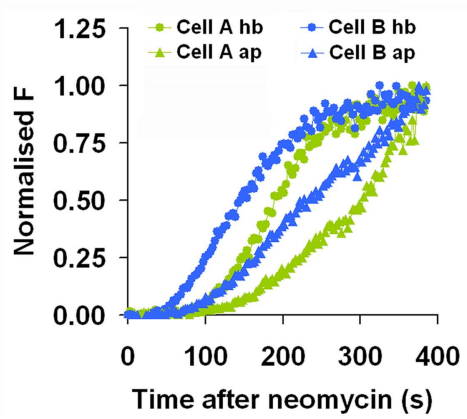

Figure 3. Time course of annexin V binding in response to perfusion of neomycin. $\boldsymbol{a}$, Confocal images captured at intervals (in seconds) after the onset of local perfusion with 1 mm neomycin. Labeling is first seen on the hair bundle, within $75 \mathrm{~s}$ of neomycin application. Pericuticular membrane staining is first detectable $\sim 150 \mathrm{~s}$ after the onset of neomycin application. Scale bar, $5 \mu \mathrm{m}$. $\boldsymbol{b}$, Diagram of the organ of Corti indicating the region (gray box) that was analyzed. $\boldsymbol{c}$, Time course of the change in fluorescence intensity (obtained by subtraction of the preapplication fluorescence signal, $F_{0}$ ) from regions of interest centered on the hair bundle (blue) and the perimeter of the apical surface of the hair cell (red). The fluorescence signal from the hair bundle reaches a steady level at $\sim 250 \mathrm{~s}$, whereas the signal in the perimeter region continues to increase. Data are mean \pm SEM from six cells. Data are representative of four separate experiments. $\boldsymbol{d}$, Normalized fluorescence signal measured from the hair bundle (circles) and the apical perimeter (triangles) of hair cells A (green symbols) and B (blue symbols) indicated by the arrows in $\boldsymbol{a}$.

Immunogold labeling with antibodies to Alexa Fluor 488 was used to study the distribution of fluorescent annexin $\mathrm{V}$ on neomycin-treated hair cells at the ultrastructural level (Fig. $2 g, h$ ). The peripheral punctae observed by fluorescence microscopy corresponded to cell surface blebs, which contained cytoplasm, vesicles, and large empty vacuoles. Labeling of the stereociliary membrane was also observed, but many hair bundle-associated blebs were not labeled (Fig. $2 g$ ).

\section{Neomycin induced PS externalization is rapid}

Real-time confocal imaging was used to ascertain the time course of neomycin-induced annexin V labeling of hair cells (Fig. 3). Typically within $\sim 75$ s of the onset of the perfusion of $1 \mathrm{~mm}$ neomycin from a micropipette directed at the organ of Corti, a fluorescent signal was detected in the hair bundles of most outer hair cells. Within an additional $\sim 75 \mathrm{~s}$, a fluorescent signal was detected at the periphery of the apical surface of the hair cells (Fig. $3 a, c, d)$. As neomycin superfusion continued, the signal in the hair bundle reached a plateau, and that from the periphery of the hair cell apex continued to increase (Fig. $3 a, c, d$ ). Although the appearance of annexin $\mathrm{V}$ labeling was delayed in some cells, the lag between the fluorescence signal appearing in the hair bundle and in the apical periphery remained approximately constant at 75$100 \mathrm{~s}$ (Fig. 3d, cells A and B).

Neomycin causes a rapid increase in whole-cell capacitance Whole-cell capacitance was monitored to determine whether neomycin-induced blebbing at the apical membrane surface and PS externalization occur concomitantly with an increase in the surface area of plasma membrane of the hair cell. Measurements were made under control conditions and during superfusion by 1 mM neomycin on the same outer hair cell (Fig. $4 a$ ). After $\sim 2$ min $(146 \pm 33 \mathrm{~s})$ of neomycin exposure, the whole-cell capacitance had increased from $6.4 \pm 0.6$ to $9.6 \pm 0.9 \mathrm{pF}(n=8$ cells; $p<$
$0.01)$. The whole-cell capacitance did not change significantly after $\sim 2$ min under control conditions: $6.8 \pm 1.0$ to $7.0 \pm 1.1 \mathrm{pF}$ $(n=4$ cells $)$.

\section{PS externalization and bleb formation is not blocked by} LY294002, SQ22536, or brefeldin A

The externalization of PS around the periphery of the apical surface occurs on the surface of blebs that form simultaneously in response to neomycin treatment. Bleb formation in adult guinea pig hair cells is associated with sodium influx, and can be reduced by blocking cAMP synthesis, inhibition of PI-3 kinase, or blockade of intracellular vesicle transport (Shi et al., 2007). The adenylate cyclase inhibitor SQ22536 (0.5 mM), the PI-3 kinase inhibitor LY294002 $(10 \mu \mathrm{M})$, and the vesicle transport inhibitor brefeldin A $(50 \mu \mathrm{M})$ did not elicit annexin V labeling before neomycin exposure (Fig. $4 c-e$ ), nor did they inhibit neomycininduced PS externalization or blebbing in mouse cochlear cultures (Fig. $4 c^{\prime}-e^{\prime}$ ). The adenylate cyclase agonists, forskolin and acetyl forskolin, did not stimulate PS externalization (data not shown). Ouabain, an inhibitor of the $\mathrm{Na}^{+} \mathrm{K}^{+}$ATPase that should elevate intracellular sodium, caused a decrease in the rate of PS externalization (Fig. $4 f, g$ ) and a reduction in the extent to which labeling extended into more apical cochlear locations (data not shown).

\section{Pretreatment with EGTA blocks PS externalization}

The styryl dye FM1-43 and aminoglycoside antibiotics are both thought to enter hair cells via their apically located mechanotransducer channels (Gale et al., 2001; Meyers et al., 2003; Marcotti et al., 2005). Live dual-channel confocal imaging of hair cells simultaneously exposed to FM1-43 and neomycin in the presence of Alexa Fluor 647-conjugated annexin V showed that PS externalization followed shortly after FM1-43 dye loading (supplemental Movie 1, available at www.jneurosci.org as supple- 

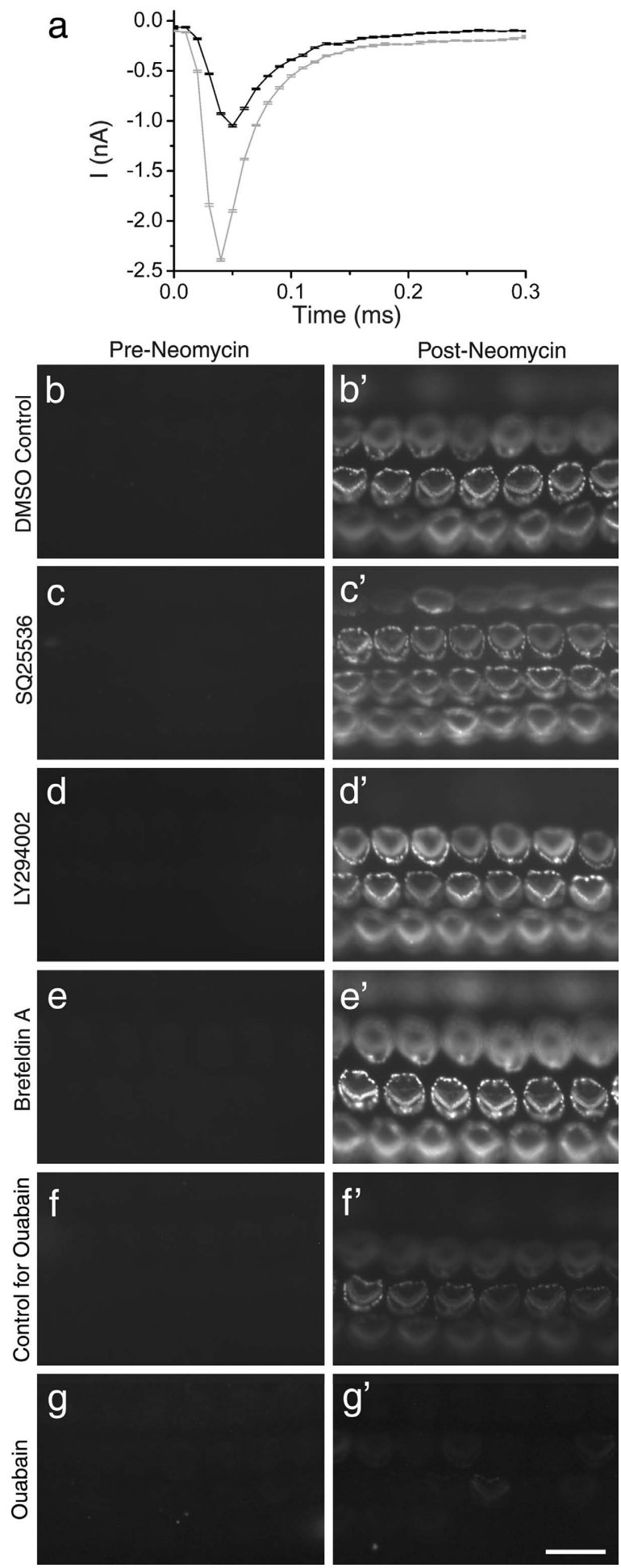

Figure 4. Neomycin-induced changes in whole-cell capacitance and effects of SQ225536, LY294002, brefeldin A, and ouabain. $\boldsymbol{a}$, Transient capacitative currents (note timescale on $x$-axis) in response to a $10 \mathrm{mV}$ hyperpolarizing voltage step (applied at $t=0 \mathrm{~ms}$ ) from a holding potential of $-84 \mathrm{mV}$ for a representative outer hair cell in control conditions before (black line) and after (gray line) $\sim 2$ min exposure to 1 mm neomycin. Traces are averaged from 10 repetitions of the voltage step. Whole-cell capacitance was calculated from the charge transfer during the voltage step, obtained by numerically integrating the area within the current transient. The measured whole-cell capacitances for these traces are $6.3 \pm 0.2 \mathrm{pF}$ (control) and $13 \pm 1 \mathrm{pF}$ (neomycin exposure). $\boldsymbol{b}-\boldsymbol{g}$, Fluorescence images of basal-coil cochlear cultures that were incubated in the presence of Alexa Fluor 488 annexin V for 30 min in 0.1\% DMSO (b), 0.5 mm SQ225536 (c), $10 \mu \mathrm{M} \mathrm{LY294002} \mathrm{(d),} 50 \mu \mathrm{m}$ brefeldin A (e), control solution $(\boldsymbol{f})$, or $34 \mu \mathrm{m}$ ouabain $(\boldsymbol{g})$, before the addition of $1 \mathrm{~mm}$ neomycin. Images were captured $1 \mathrm{~min}$ before $(\boldsymbol{b}-\boldsymbol{g})$ and $10 \mathrm{~min}$ after $\left(\boldsymbol{b}^{\prime}-\boldsymbol{g}^{\prime}\right)$ the addition of neomycin. Scale bar: (in $\boldsymbol{g}$ ) $\boldsymbol{b}-\boldsymbol{g}, 20 \mu \mathrm{m}$. mental material). FM1-43 dye loading into hair cells can be blocked by pretreating cochlear cultures with calcium chelators (Gale et al., 2001), a procedure that disrupts the tips links that are thought to gate the mechanotransducer channel of the hair cell (Assad et al., 1991). Preexposure to calcium chelators can also block neomycin-induced membrane blebbing in the hair cells of apical-coil cochlear cultures, but not in all the hair cells of basalcoil cultures (Gale et al., 2001). After exposure to EGTA and return to saline containing normal levels of extracellular $\mathrm{Ca}^{2+}$, neomycin-induced PS externalization and blebbing were no longer observed in apical-coil cultures (Fig. $5 a, b$ ). In basal-coil cultures, a proportion $(38.9 \pm 2.9 \%$ for middle of basal coil; $n=$ 4 areas counted, 255 cells total) of the calcium chelator-treated cells externalized PS in response to neomycin treatment (Fig. $5 c, d)$.

\section{Phosphatidylinositol 4,5-biphosphate-reporter expression reduces PS externalization}

Neomycin is known to interact with phosphatidylinositol 4,5biphosphate (PIP2) (Schacht, 1976, 1978, 1979; Jiang et al., 2006) and can, like $\mathrm{Ca}^{2+}$, cause lipid scrambling in erythrocyte ghosts. Neomycin and $\mathrm{Ca}^{2+}$ can both cluster PIP2, and the PIP2-binding pleckstrin homology $(\mathrm{PH})$ domain of phospholipase $\mathrm{C} \delta 1$ (PLC $\delta 1$ ) has been shown to block $\mathrm{Ca}^{2+}$-induced lipid scrambling in erythrocyte ghosts (Bucki et al., 2000). Neomycininduced PS externalization was therefore examined in hair cells that were overexpressing the PH domain of PLC $\delta 1$ tagged with EGFP (PLC $\delta 1-P H-E G F P)$.

In untreated cultures, PLC $\delta 1-\mathrm{PH}-\mathrm{EGFP}$ revealed a uniform distribution of PIP2 at the apex of the hair cells: both the hair bundle and the surrounding apical membrane were labeled (Fig. $5 e$ ). In the majority of hair cells expressing the PLC $\delta 1$-PH-EGFP ( $82 \% ; 21$ of 24 cells, 16 of 21 cells; $n=2$ experiments), PS externalization in response to neomycin treatment was either not observed or much reduced (Fig. 5f). Cells expressing PLC $\delta 1-\mathrm{PH}-$ EGFP loaded normally with FM1-43 (Fig. 5f). Although a general trend was observed for cells expressing high levels of PLC $\delta 1-\mathrm{PH}-$ EGFP not to externalize PS, it should be noted that a failure to externalize PS in response to neomycin was also observed (1) in some cells expressing low levels of the PLC $\delta 1-P H-E G F P$ construct, (2) in a proportion of cells expressing either high or low levels of an EGFP-tagged $\gamma$-actin construct (34\%; 12 of 33 cells, 8 of 25 cells; $n=2$ experiments), and (3) in a number of nontransfected cells in these gene-gun transfected cultures. The failure of some PH-domain expressing hair cells to externalize PS in response to neomycin treatment was therefore likely to be attributable, in part, to the biolistic transfection procedure.

In the minority of PLC $\delta 1$-PH-EGFP-expressing cells that did externalize PS in response to neomycin treatment, labeling of the apical plasma membrane became distinctly patchy (Fig. $5 g$ ). Many regions that were not labeled by PLC $\delta 1-P H-E G F P$ (i.e., without PIP2 in the inner leaflet) were stained by annexin V (i.e., had PS in their external leaflet), and some patches were observed that were not labeled with either PLC $\delta 1-P H-E G F P$ or annexin V (Fig. $5 g$ ). In cells that had been treated with neomycin in the presence of both annexin V and FM1-43, much of the FM1-43 partitioned into membrane blebs that were not sites of PS externalization (Fig. 5h). These observations indicate that much of the membrane that labels with annexin $\mathrm{V}$ after neomycin exposure is atypical. 

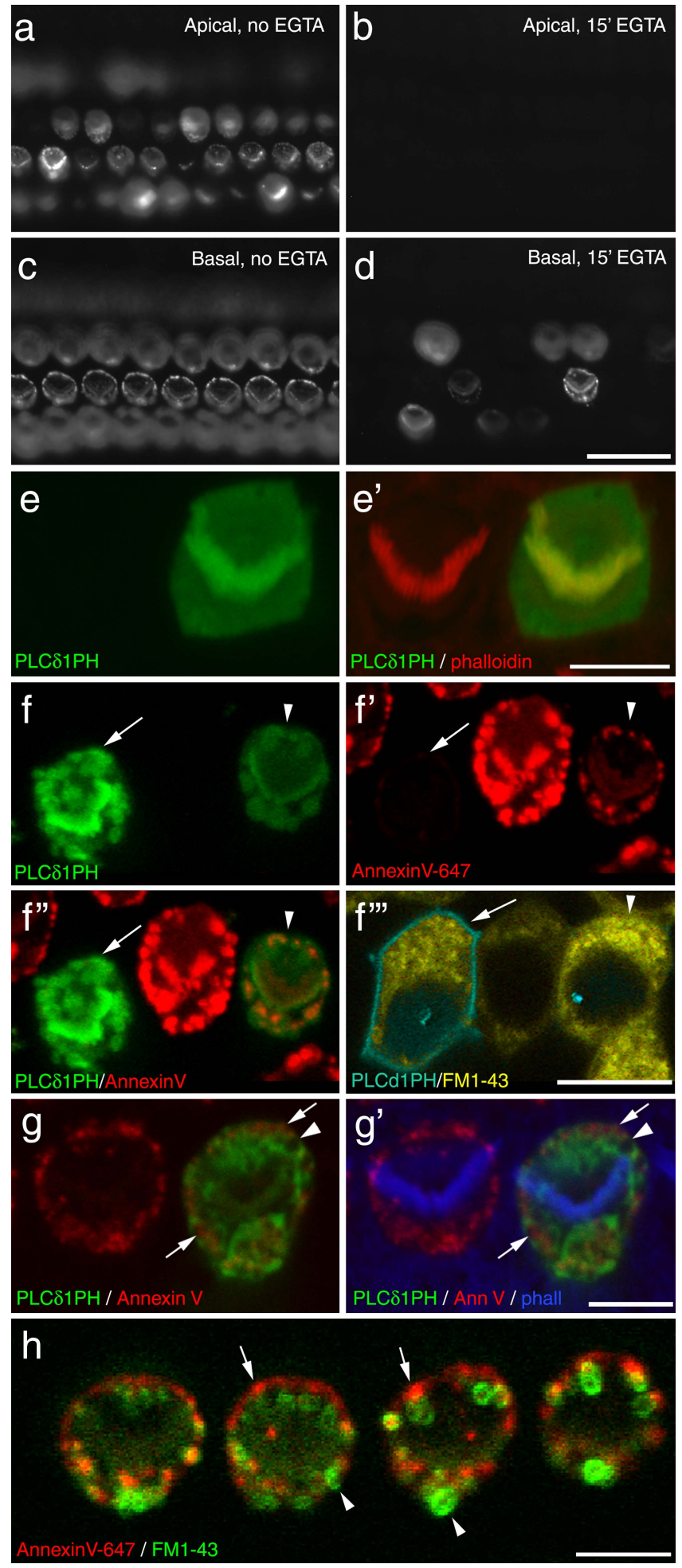

Figure 5. Effects of calcium chelation and PH domain expression. $\boldsymbol{a}-\boldsymbol{d}$, Wide-field images of apical $(\boldsymbol{a}, \boldsymbol{b})$ and basal $(\boldsymbol{c}, \boldsymbol{d})$ coil cochlear cultures that were incubated in saline $(\boldsymbol{a}, \boldsymbol{c})$ or saline containing $5 \mathrm{~mm}$ EGTA for $15 \mathrm{~min}$, washed, incubated in saline for $45 \mathrm{~min}$, and then exposed to 1 mm neomycin in the presence of Alexa Fluor 488 annexin V. Images were captured 10 min after the addition of neomycin. Scale bar: (in $\boldsymbol{d}) \boldsymbol{a}-\boldsymbol{d}, 20 \mu \mathrm{m} . \boldsymbol{e}$, Confocal images of a pair of outer hair cells from a saline-treated ( $15 \mathrm{~min}$ ) control culture that was fixed and double labeled with Texas Red-conjugated phalloidin. The cell on the right was transfected with PLC $\delta 1-P H-E G F P$. Scale bar, $5 \mu \mathrm{m}$. $\boldsymbol{f}$, Live confocal images showing two PLC $\delta 1-\mathrm{PH}-\mathrm{EGFP}$ transfected hair cells in a cochlear culture that had been exposed to 1 mm neomycin and $3 \mu \mathrm{m}$ FM1-43 in the presence of Alexa Fluor 647 annexin V. The cell on the left (arrow) expresses a high level of PLC $\delta 1 P H$ domain and that on the right (arrowhead) is expressing at a lower level. The cell on the right has responded to neomycin with PS externalization, whereas that on the left has not. Both cells bleb
Effects of calcium ionophores, ATP, and high extracellular calcium

PS externalization in a variety of cell types can be caused by activation of a $\mathrm{Ca}^{2+}$-dependent lipid scramblase (Bevers et al., 1999). Neomycin caused a small transient increase in intracellular calcium $\left(\mathrm{Ca}^{2+}{ }_{\mathrm{i}}\right)$ in hair cells (Fig. $\left.6 a, b\right)$. This response was abolished in nominally calcium-free saline (data not shown), indicating that it requires $\mathrm{Ca}^{2+}$ influx and that extracellular $\mathrm{Ca}^{2+}$ is the source of the signal. Neomycin-induced membrane blebbing was, however, observed in calcium-free saline (Fig. $6 c$ ), and although annexin $\mathrm{V}$ labeling was not seen (because the binding of annexin V to PS is calcium dependent), after neomycin washout and the addition of annexin $\mathrm{V}$ in the presence of calcium, labeling of the blebs and the hair bundles was observed (Fig. $6 d$ ), indicating that PS externalization had occurred in calcium-free saline. The simplest explanation is therefore that PS externalization is not attributable to neomycin-induced $\mathrm{Ca}^{2+}$ entry per se, but neomycin may, like $\mathrm{Ca}^{2+}$, be able to cluster PIP2 and activate a scramblase. Attempts were therefore made to elevate intracellular free $\mathrm{Ca}^{2+}$ and thereby stimulate PS externalization in hair cells in the absence of neomycin.

The calcium ionophore, ionomycin, failed to elicit PS externalization in hair cells (Fig. 6e), although it did cause the rapid externalization of PS in Hensen's cells, a cell type that lies along the lateral edge of the organ of Corti (Fig. $6 f$ ). A similar effect (i.e., PS externalization in Hensen's cell but not in hair cells) was also observed with the calcium ionophore A23187 (data not shown). ATP-sensitive purinoreceptors are widely expressed in the cochlea, on both hair and supporting cells, and their activation by ATP should lead to an increase in $\mathrm{Ca}^{2+}{ }_{\mathrm{i}}$ (Ashmore and Ohmori, 1990; Dulon et al., 1993; Chen and Bobbin, 1998; Housley et al., 1999; Järlebark et al., 2000; Lagostena and Mammano, 2001; Gale et al., 2004; Piazza et al., 2007; Lahne and Gale, 2008). ATP, at concentrations ranging from 0.1 to $1.0 \mathrm{~mm}$, did not cause PS externalization in hair cells, Hensen's cells, or other supporting cells within and surrounding the organ of Corti (Fig. $6 g$ ).

Although PS externalization could not be elicited in cochlear hair cells with either ionomycin or ATP, the addition of $20 \mathrm{mM}$ $\mathrm{CaCl}_{2}$ to the bath solution did cause the rapid labeling of hair bundles with annexin V (Fig. 6h). This response was only observed with cultures that had been maintained for $2 \mathrm{~d}$ or longer in vitro, and not in 1-d-old cultures, and was primarily observed in the basal-coil cultures. Annexin V labeling in 2-d-old basal-coil cultures could not be elicited by the addition of either $20 \mathrm{~mm}$ $\mathrm{MgCl}_{2}$ (Fig. 6i) or $30 \mathrm{~mm} \mathrm{NaCl}$ (data not shown), indicating that the response observed with $20 \mathrm{mM} \mathrm{CaCl}_{2}$ was $\mathrm{Ca}^{2+}$-specific and not attributable simply to a divalent ion effect or hyperosmotic shock. Annexin V labeling in response to high extracellular $\mathrm{Ca}^{2+}$ did not occur in Hensen's cells. In hair cells, it occurred predominantly on the hair bundles and, unlike the response to neomycin (Fig. 6j), was not accompanied by bleb formation (Fig. $6 k-m$ ),

\section{$\leftarrow$}

and load with FM1-43. Scale bar, $10 \mu \mathrm{m} . \boldsymbol{g}$, Confocal image of a pair of outer hair cells that were treated with $1 \mathrm{~mm}$ neomycin (15 min) in the presence of Alexa Fluor 647 annexin V, fixed, and double labeled with Alexa Fluor 350-conjugated phalloidin. The cell on the left expresses

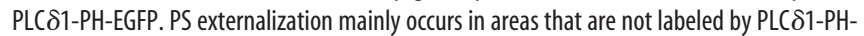
EGFP (arrows), and patches are observed that are not a labeled by either marker (arrowhead). Scale bar, $5 \mu \mathrm{m}$. $\boldsymbol{h}$, Live confocal image from a culture that had been exposed to neomycin in the presence of Alexa Fluor 647 annexin V followed by the application of FM1-43. Note how the FM1-43 often partitions within membrane blebs (arrowheads) that are not labeled by annexin $\mathrm{V}$ (arrows). Image was obtained by spectral analysis of the fluorescence emission using the Zeiss Meta detector. Scale bar, $5 \mu \mathrm{m}$. 

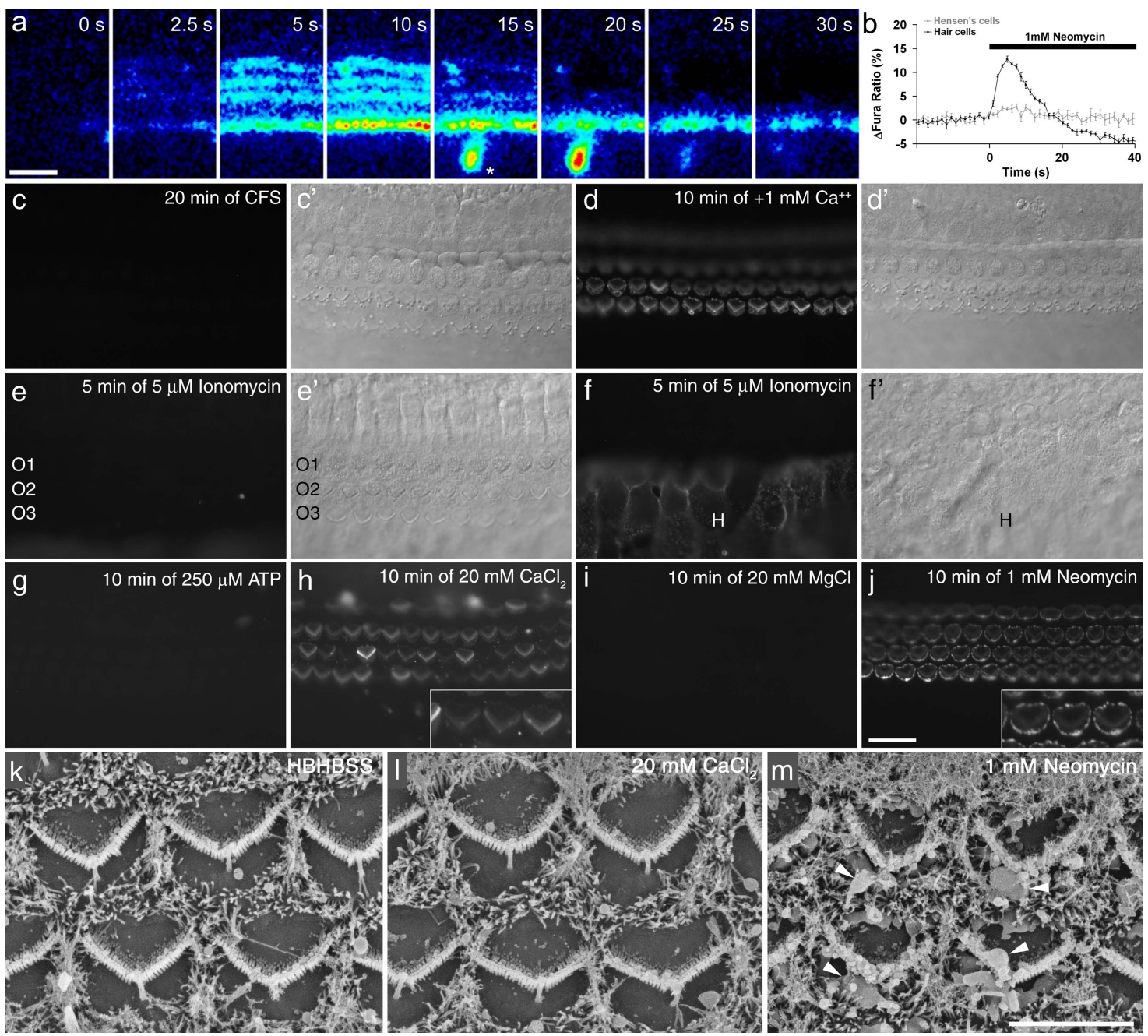

Figure 6. Effects of calcium on PS externalization. $\boldsymbol{a}$, Sequence of images showing changes in $\mathrm{Ca}^{2+}{ }_{\mathrm{i}}$ in hair cells in response to the application of 1 mm neomycin. From left to right, the panels show the changes in fura- 2 ratio (wide-field imaging) at the times indicated during brief exposure ( $40 \mathrm{~s}$ ) to $1 \mathrm{~mm}$ neomycin. Times after application, and color scaling for ratio changes are indicated. The asterisk indicates a spontaneous $\mathrm{Ca}^{2+}$ event occurring in the greater epithelial ridge (Tritsch et al., 2007). $\boldsymbol{b}$, Graph showing the change in fura-2 ratio in hair cells and Hensen's cells after application of $1 \mathrm{~mm}$ neomycin. Data are the averages from five cells of the recording in $\boldsymbol{a}$ and are representative of at least three different experiments. $\boldsymbol{c}, \boldsymbol{d}$, Fluorescence $(\boldsymbol{c}, \boldsymbol{d})$ and Nomarski interference contrast $\left(\boldsymbol{c}^{\prime}, \boldsymbol{d}^{\prime}\right)$ images of a basal-coil cochlear culture that was incubated in 1 mм neomycin in nominally calcium-free saline (CFS) for 20 min in the presence of Alexa Fluor 488 annexin $V\left(\boldsymbol{c}, \boldsymbol{c}^{\prime}\right)$. After washout of both compounds, Alexa Fluor 488 annexin V was added in normal, calcium-containing saline and the culture was imaged after 10 min $\left(\boldsymbol{d}, \boldsymbol{d}^{\prime}\right)$. Blebs that formed in the absence of calcium, label with annexin $V$ in the presence of calcium. $\boldsymbol{e}, \boldsymbol{f}$, Fluorescence $(\boldsymbol{e}, \boldsymbol{f})$ and Nomarski interference contrast $\left(\boldsymbol{e}^{\prime}, \boldsymbol{f}^{\prime}\right)$ images of a basal-coil cochlear culture incubated in $5 \mu \mathrm{m}$ ionomycin in the presence of Alexa Fluor 488 annexin $V$ for $5 \mathrm{~min}$. The image in $\boldsymbol{e}$ is focused on the apical surfaces of the outer hair cells $(01,02,03$, outer hair cells in rows 1,2 , and 3, respectively), and the image in $f$ is focused on the surfaces of the Hensen's cells $(\mathrm{H}) . \boldsymbol{g}$-j, Fluorescence images of 2-d-old basal-coil cochlear cultures incubated for 10 min in Alexa Fluor 488 annexin $V$ in saline with either $250 \mu \mathrm{m} \mathrm{ATP}(\boldsymbol{g})$, an additional $20 \mathrm{~mm} \mathrm{CaCl}(\boldsymbol{h})$, an additional $20 \mathrm{~mm} \mathrm{MgCl}(\boldsymbol{i})$, or $1 \mathrm{~mm}$ neomycin (j). $\boldsymbol{k}$ - $\boldsymbol{m}$, Scanning electron micrographs of 2-d-old basal-coil cochlear cultures incubated for 15 min in saline $(\boldsymbol{k}), 20 \mathrm{~mm} \mathrm{CaCl}(\boldsymbol{I})$, or $1 \mathrm{~mm}$ neomycin $(\boldsymbol{m})$. Scale bars: (in $\boldsymbol{j}) \boldsymbol{c}-\boldsymbol{j}, 20 \mu \mathrm{m}$; (in $\boldsymbol{m}) \boldsymbol{k}-\boldsymbol{m}, 5 \mu \mathrm{m}$.

providing evidence that blebbing and PS externalization can be independent events.

Calcium imaging was used to determine the extent to which the application of high extracellular $\mathrm{Ca}^{2+}$, ionomycin, and ATP affected $\mathrm{Ca}^{2+}{ }_{\mathrm{i}}$. Non-confocal fura-2 imaging indicated that the addition of $20 \mathrm{mM} \mathrm{Ca}^{2+}$ to 2-d-old basal-coil cultures caused a small but significant $\mathrm{Ca}^{2+}{ }_{\mathrm{i}}$ increase in hair cells, with minimal changes occurring in Hensen's cells and other surrounding cells (Fig. 7a,b,d). Ionomycin, in contrast, caused a large $\mathrm{Ca}^{2+}{ }_{\mathrm{i}}$ increase in Hensen's cells that was accompanied by a smaller increase in the hair cell region (Fig. $7 c, d$ ). The increase in the hair cell region seen with ionomyin under widefield, non-confocal imaging conditions was larger than that seen with high extracellular $\mathrm{Ca}^{2+}$. Confocal $\mathrm{Ca}^{2+}{ }_{\mathrm{i}}$ imaging with Oregon Green BAPTA- 488 of cultures examined before and after ionomycin treatment revealed that the $\mathrm{Ca}^{2+}$ signal seen after ionomycin was derived from the Deiters' cells that surround and lie beneath the hair cells (Fig. 7e). Confocal $\mathrm{Ca}^{2+}{ }_{\mathrm{i}}$ imaging with Oregon Green BAPTA488 was also used to examine and compare the responses of hair cells and Hensen's cells to the sequential application of high extracellular $\mathrm{Ca}^{2+}$, ATP, and ionomycin in the same culture (Fig. 7f). During the application of high extracellular $\mathrm{Ca}^{2+}$, a small increase in $\mathrm{Ca}^{2+}{ }_{\mathrm{i}}$ was observed in the hair cells, but not in Hensen's cells. The application of $100 \mu \mathrm{M}$ ATP resulted in a larger increase in $\mathrm{Ca}^{2+}{ }_{\mathrm{i}}$ in both hair cells and Hensen's cells, as did perfusion with $10 \mu \mathrm{M}$ ionomycin. Although $\mathrm{Ca}^{2+}{ }_{\mathrm{i}}$ levels recovered in hair cells during perfusion with either high $\mathrm{Ca}^{2+}$, ATP, or ionomycin, and also in Hensen's cells during ATP application, $\mathrm{Ca}^{2+}{ }_{\mathrm{i}}$ levels in Hensen's cells remained elevated and, after a brief period, continued to increase during ionomycin exposure. The differential behavior of hair cells and Hensen's cells observed in response to ionomycin may be accounted for by a much higher $\mathrm{Ca}^{2+}$ buffering capacity or $\mathrm{Ca}^{2+}$ extrusion rate in hair cells. 

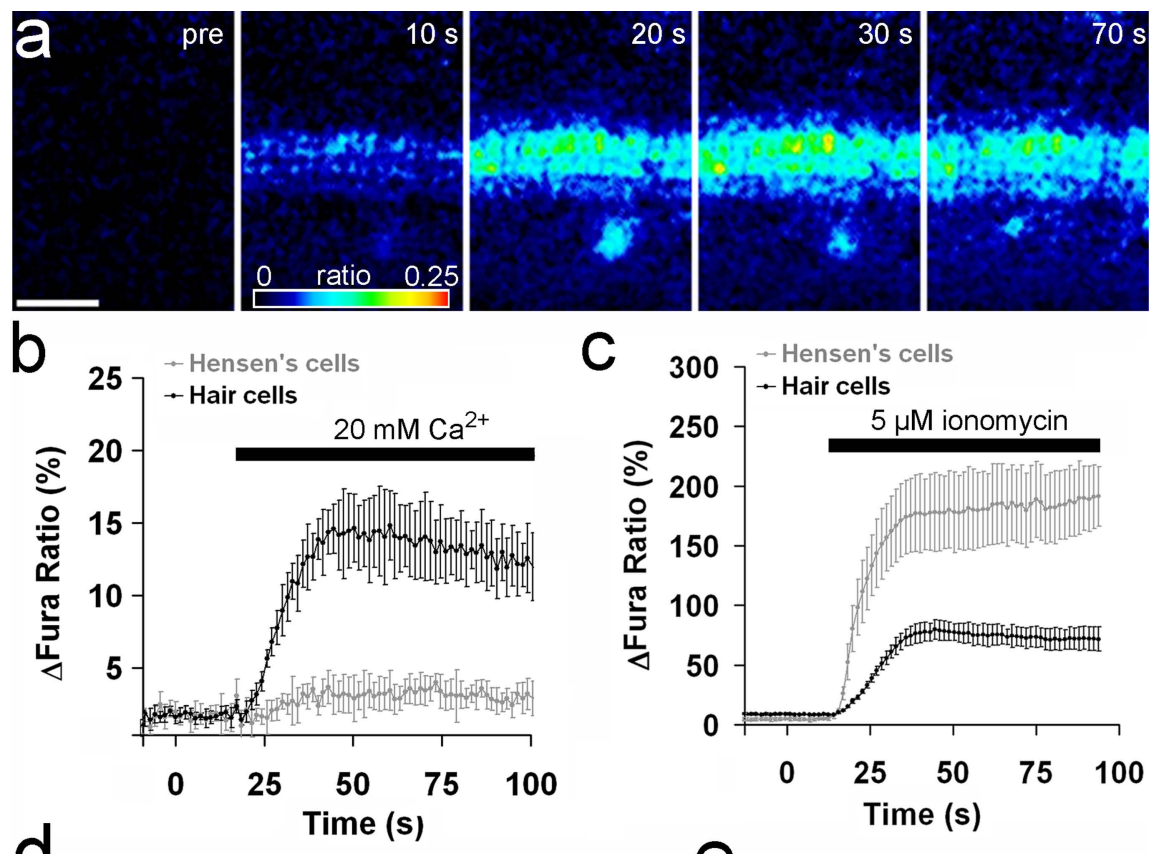

d
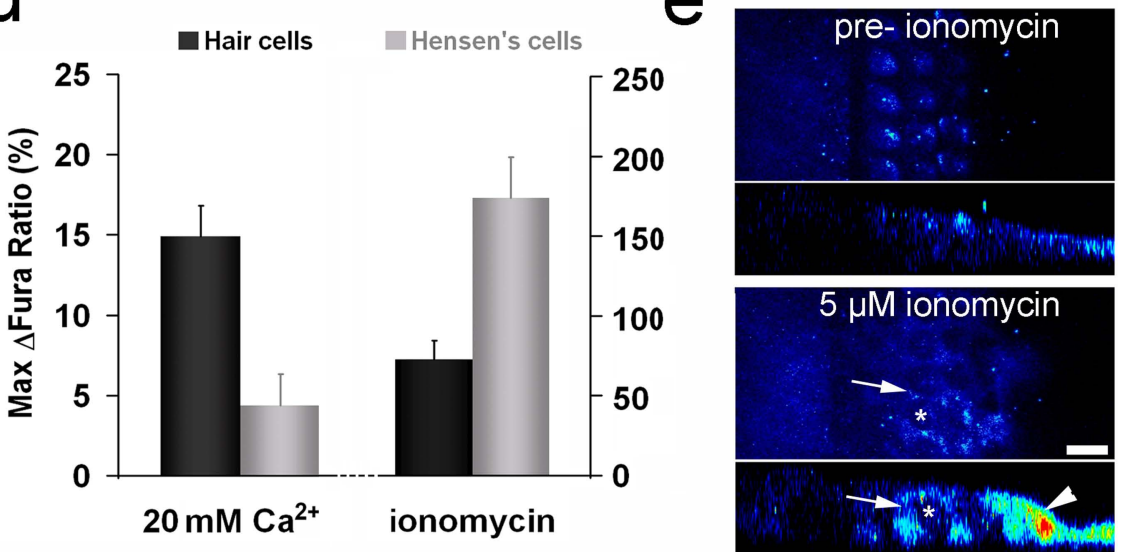

$\left\{\begin{array}{l}\rightarrow \text { Hensen's cell } \\ \rightarrow \text { Hair cell }\end{array}\right.$

$100 \mu \mathrm{M}$ ATP

$10 \mu \mathrm{M}$ ionomycin

\section{$20 \mathrm{mM} \mathrm{Ca}^{2+}$}

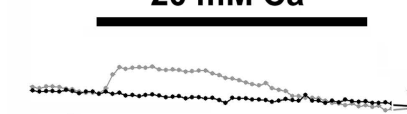

状察

$40 \mathrm{~s}$
Figure 7. $\quad \mathrm{Ca}^{2+}{ }_{\mathrm{i}}$ responses to application of high extracellular $\mathrm{Ca}^{2+}$ or ionomycin. $\boldsymbol{a}$, Sequence of images showing changes in $\mathrm{Ca}^{2+}{ }_{i}$ in hair cells in response to application of $20 \mathrm{~mm} \mathrm{Ca}{ }^{2+}$. Left panel, Fura $380 \mathrm{~nm}$ signal showing the cellular structure in the cochlear culture. The remaining panels show the changes in fura-2 ratio resulting from $20 \mathrm{~mm} \mathrm{Ca}^{2+}$ application. Times after application, and color scaling for ratio changes are indicated. The asterisk indicates a spontaneous $\mathrm{Ca}^{2+}$ event occurring in the greater epithelial ridge (Tritsch et al., 2007). $\boldsymbol{b}$, Data pooled from four different experiments showing the change in fura-2 ratio in hair cells and Hensen's cells after bath application of $20 \mathrm{~mm} \mathrm{Ca}^{2+}$.c, Data showing the fura- 2 changes in Hensen's cells and the hair cell region after bath application of $5 \mu$ m ionomycin. $d$, Quantification of the maximum change in $\mathrm{Ca}^{2+}{ }_{\mathrm{i}}$ after exposure to $20 \mathrm{~mm}$ $\mathrm{Ca}^{2+}$ (left) or $10 \mu \mathrm{m}$ ionomycin (right). Dark bars, Hair cells (left) and for ionomycin, hair cell region (right); gray bars, Hensen's cells for both. $e$, Confocal imaging of changes in $\mathrm{Ca}^{2+}{ }_{i}$ observed using Oregon Green BAPTA-488 before and after treatment with $5 \mu \mathrm{m}$ ionomycin. Single confocal images at a focal plane above the nucleus of the hair cells are shown with the corresponding orthogonal projection below. Ionomycin causes a strong increase in the $\mathrm{Ca}^{2+}{ }_{i}$ in the Hensen's cells (arrowhead) and the Deiters' cells (arrows), whereas the hair cells (asterisk) show little or no response.f, Traces from a confocal imaging series using 0 regon Green BAPTA-488. The traces represent the responses of single outer hair cells and single Hensen's cells to local, sequential pipette application of $20 \mathrm{~mm} \mathrm{Ca}{ }^{2+}, 100 \mu \mathrm{M} \mathrm{ATP}$, and $10 \mu \mathrm{m}$ ionomycin with intervals of $\sim 5 \mathrm{~min}$ (asterisk) between each application (traces are representative of four separate experiments). Scale bars: $\boldsymbol{a}, 50 \mu \mathrm{m} ; \boldsymbol{e}, 10 \mu \mathrm{m}$. Pooled data shown are mean \pm SEM.
PS-annexin V complexes are rapidly internalized at $37^{\circ} \mathrm{C}$

When cochlear cultures were treated with neomycin for $15 \mathrm{~min}$, washed, and then exposed to fluorescent annexin $\mathrm{V}$, labeling of the apical membrane was readily detected (data not shown). If cultures were exposed to neomycin for $15 \mathrm{~min}$, washed, and then incubated in medium at either 20 or $37^{\circ} \mathrm{C}$ for $2 \mathrm{~h}$ before the addition of fluorescent annexin $\mathrm{V}$, labeling of the apical surface was still observed in cultures that had been incubated at $20^{\circ} \mathrm{C}$ but was substantially reduced in those that had been incubated at $37^{\circ} \mathrm{C}$ (Fig. $\left.8 a, b\right)$. This indicated that, at $37^{\circ} \mathrm{C}$, PS was either flipping back into the inner leaflet, or that the membrane with externalized PS was being removed, either by internalization or shedding from the cell surface. To distinguish between these possibilities, cochlear cultures were exposed to neomycin for 5 min in the presence of fluorescent annexin $\mathrm{V}$, washed to remove both compounds, and incubated at either 20 or $37^{\circ} \mathrm{C}$ for up to $2 \mathrm{~h}$. They were fixed at different time points after neomycin exposure, labeled with Texas Red phalloidin, and then examined by confocal microscopy. Immediately after neomycin treatment, annexin $\mathrm{V}$ labeling was restricted to the apical surface of the hair cells (Fig. 8c). After 30 min recovery at $37^{\circ} \mathrm{C}$, a proportion of the fluorescent label became distributed in a punctate manner throughout the apical cytoplasm of the hair cell, in the region lying between the nucleus and the cuticular plate (Fig. $8 d$ ). Intracellular label extended deeper within the cells by $60 \mathrm{~min}$ of recovery at $37^{\circ} \mathrm{C}$ (Fig. 8e) and surface labeling was substantially reduced after $2 \mathrm{~h}$ (Fig. $8 f$ ). Triple labeling with $4^{\prime}, 6^{\prime}$-diamidino-2phenylindole (DAPI) revealed that almost all the internalized label remained within the supranuclear apical cytoplasm and was not transported to the basal, synaptic pole of the hair cell (Fig. 8f). Internalization of the label failed to occur at all when the labeled cultures were incubated for $2 \mathrm{~h}$ at $20^{\circ} \mathrm{C}$ (Fig. $8 g$ ). These observations suggested that membrane containing the externalized PS with bound annexin V was being removed from the apical surface via an endocytotic process. To determine whether any membrane shedding was also occurring during the recovery, time-lapse analysis was performed over the $2 \mathrm{~h}$ recovery period using spinning-disc confocal microscopy. No discernable shedding of the fluorescent signal into the medium above the apical surface could be detected using this approach, revealing that the majority and possibly all the membrane with 

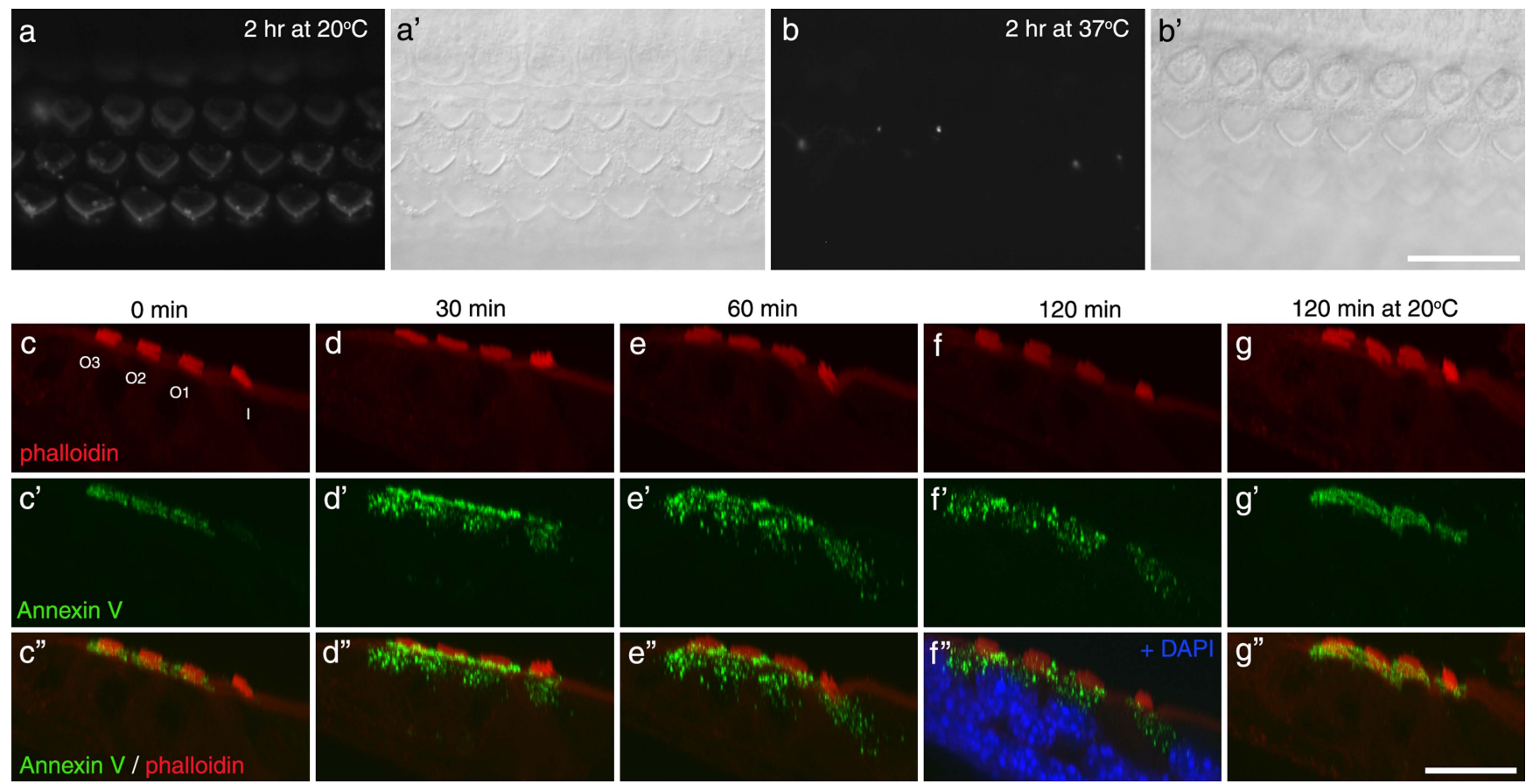

Figure 8. Neomycin-induced PS externalization is reversible. $\boldsymbol{a}, \boldsymbol{b}$, Fluorescence $(\boldsymbol{a}, \boldsymbol{b})$ and Nomarski interference contrast $\left(\boldsymbol{a}^{\prime}, \boldsymbol{b}^{\prime}\right)$ images of basal-coil cochlear cultures that were incubated in $1 \mathrm{~mm}$ neomycin for $15 \mathrm{~min}$, washed in saline, and then incubated for $2 \mathrm{~h}$ at either $20^{\circ} \mathrm{C}\left(\boldsymbol{a}, \boldsymbol{a}^{\prime}\right)$ or $37^{\circ} \mathrm{C}\left(\boldsymbol{b}, \boldsymbol{b}^{\prime}\right)$ before the addition of Alexa 488 annexin $\mathrm{V}$. Images were captured 5 min after the addition of annexin V. $\mathbf{c}-\boldsymbol{g}$, Orthogonal Z-projections of confocal image stacks of organs of Corti that, after neomycin-induced Alexa Fluor 488 annexin $V$ labeling ( $g r e e n)$, had been allowed to recover for 0 $\min (\boldsymbol{c}), 30 \mathrm{~min}(\boldsymbol{d}), 60 \mathrm{~min}(\boldsymbol{e})$, or $120 \mathrm{~min}$ at $37^{\circ} \mathrm{C}(\boldsymbol{f})$, and $120 \mathrm{~min}$ at $20^{\circ} \mathrm{C}(\boldsymbol{g})$ before fixation and labeling with phalloidin (red). At $30 \mathrm{~min}$, label is seen within the hair cells, and by $120 \mathrm{~min}$ labeling is no longer seen on the hair cell surface. Additional staining with DAPI $(\boldsymbol{f})$ reveals that labeling with annexin $V$ is located between the nucleus and the apical membrane. Internalization is not seen after 120 min recovery at $20^{\circ} \mathrm{C}(\boldsymbol{g}) . \mathbf{c} \boldsymbol{g}$ show phalloidin labeling; $\boldsymbol{c}^{\prime}-\boldsymbol{g}^{\prime}$ show Alexa Fluor 488 annexin V labeling; $\boldsymbol{c}^{\prime \prime}-\boldsymbol{g}^{\prime \prime}$ are the merges. I, Inner hair cell; $01,02,03,0$ outer hair cells in rows 1,2 , and 3, respectively. Scale bars: (in $\boldsymbol{b}, \boldsymbol{g}) \boldsymbol{a}-\boldsymbol{g}, 20 \mu \mathrm{m}$.

externalized PS was being reabsorbed or internalized by the hair cells (supplemental Movie 2, available at www.jneurosci.org as supplemental material).

\section{Hair cells recover from neomycin-induced damage}

Neomycin-treated cochlear cultures were examined by scanning (Fig. $9 a-f$ ) and transmission electron microscopy (Fig. $9 g-j$ ) to determine whether the loss of annexin $\mathrm{V}$ from the apical surface and its internalization correlated with a loss of membrane blebs. Cultures were treated with saline or $1 \mathrm{~mm}$ neomycin (in the absence of annexin V) for 5 or $30 \mathrm{~min}$ at ambient temperature, washed with saline to remove the neomycin, and incubated in medium at $37^{\circ} \mathrm{C}$ for $2 \mathrm{~h}$ before fixation. After $5 \mathrm{~min}$ of neomycin treatment, small membrane blebs were primarily located on the periphery of the apical surface of the hair cell (Fig. 9b,g). After 30 min of neomycin treatment, membrane blebs were also found associated with the hair bundles (Fig. 9c). After the $2 \mathrm{~h}$ postneomycin recovery period, the hair cells that had been treated with neomycin for 5 min exhibited almost complete recovery and were indistinguishable from those of saline-treated controls (Fig. $9 e, i)$. The hair cells that had been treated with neomycin for 30 min also exhibited a substantial degree of repair after $2 \mathrm{~h}$ of recovery at $37^{\circ} \mathrm{C}$ (Fig. 9f,j).

To determine whether hair cells could survive for longer periods after neomycin exposure, cultures were treated with saline or $1 \mathrm{~mm}$ neomycin for $30 \mathrm{~min}$ at $20^{\circ} \mathrm{C}$, washed, and then either fixed immediately or incubated for $24 \mathrm{~h}$ at $37^{\circ} \mathrm{C}$ in complete medium before fixation. Scanning electron microscopy revealed the neomycin-treated hair cells could repair the damage sustained and survive for an additional $24 \mathrm{~h}$ (supplemental Fig. 3, available at www.jneurosci.org as supplemental material).
Myosin VI mutant hair cells recover from neomycin damage but exhibit a defect in the transport of apical surface-derived vesicles

Myosin VI, the only known minus end-directed actin-based myosin motor, has been implicated in many aspects of apical endocytosis in polarized epithelial cells (for review, see Hasson, 2003; Buss et al., 2004). Mutations in myosin VI cause hair bundle defects in the Snell's waltzer $(S v)$ mouse and deafness in humans (Avraham et al., 1995; Melchionda et al., 2001). Hair cells in cochlear cultures prepared from homozygous Snell's waltzer mice load, although less well than controls, after brief exposure to FM1-43, suggesting transduction is functional (data not shown). In response to neomycin treatment, almost all the hair cells in cochlear cultures prepared from homozygous $S v / S v$ mice externalized PS in response to neomycin treatment (Fig. 10a). Also, after neomycin washout and $2 \mathrm{~h}$ incubation at $37^{\circ} \mathrm{C}$, almost all hair cells were able to recover and internalize the annexin V (Fig. 10b), as described above for cultures from wildtype animals (Fig. 8b). Scanning electron microscopy confirmed that bleb formation occurred in homozygous $S v / S v$ hair cells in response to neomycin treatment, and that the mutant hair cells can, like those in wild-type mice (Fig. 9), recover from limited exposure to neomycin (Fig. 10c-f). Confocal analysis, however, revealed that, although the fluorescent annexin $\mathrm{V}$ was internalized after recovery from neomycin treatment, most of it remained located at the very apical pole of the homozygous $S v / S v$ hair cells and did not distribute throughout the supranuclear cytoplasm as it did in hair cells from heterozygous $+/ S v$ mice (Fig. 10g,h).

\section{Discussion}

The behavior of hair cells in cultures of the early-postnatal mouse cochlea differs from that described for hair cells in acutely iso- 
5 min of HBSS $\rightarrow$ Fix

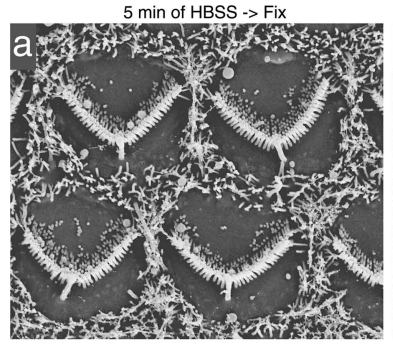

$5 \mathrm{~min}$ of HBSS $\rightarrow 2 \mathrm{hr}$ at $37^{\circ} \mathrm{C} \rightarrow \mathrm{Fix}$

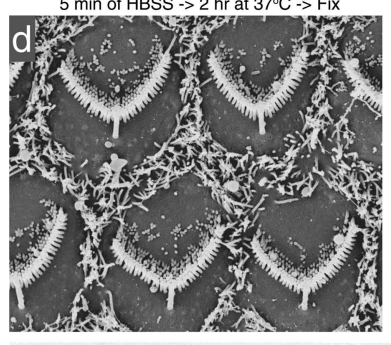

g

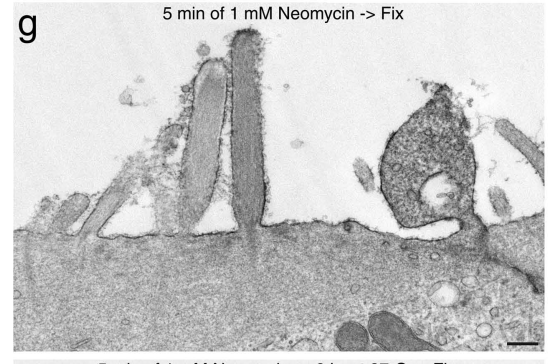

i
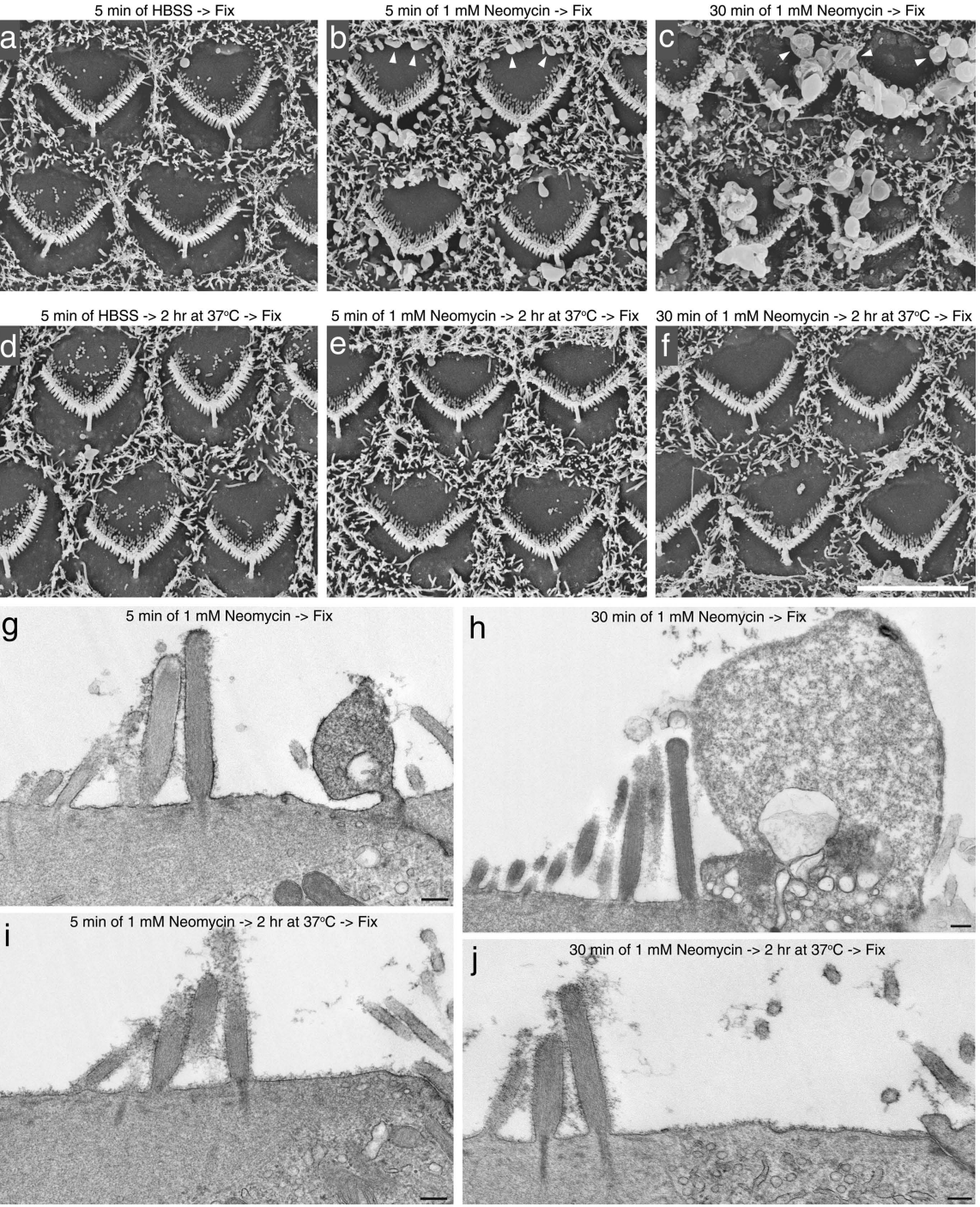

$5 \mathrm{~min}$ of $1 \mathrm{mM}$ Neomycin $->2 \mathrm{hr}$ at $37^{\circ} \mathrm{C}->\mathrm{Fix}$
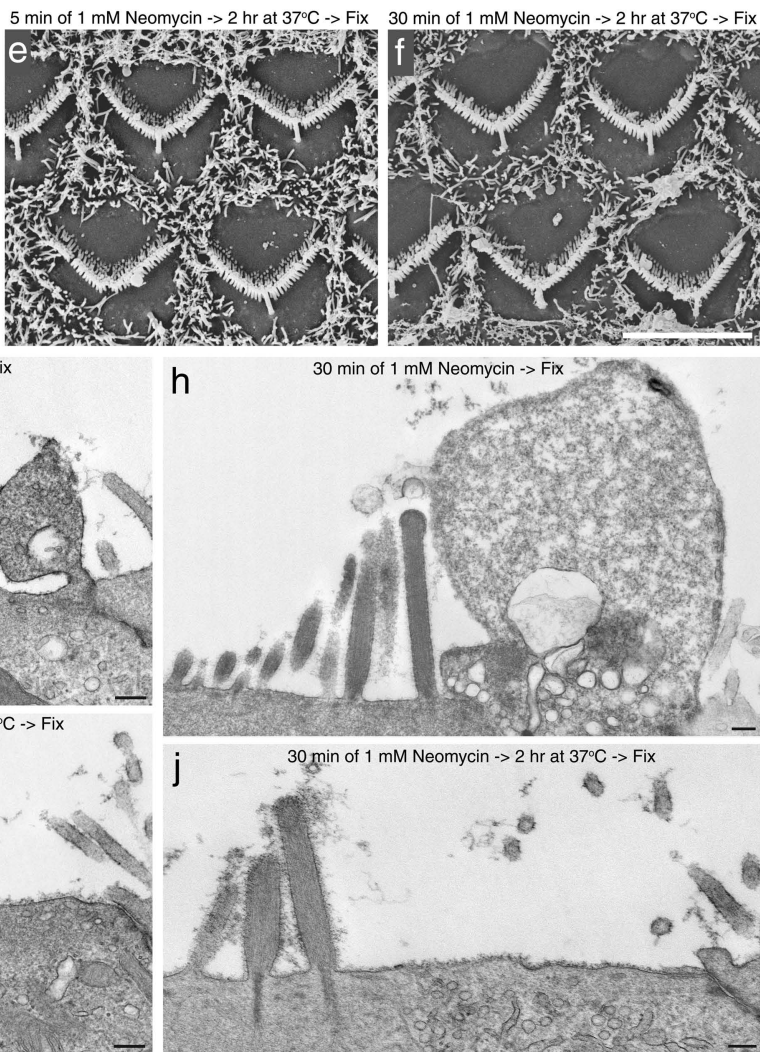

Figure 9. Scanning electron microscopic and transmission electron microscopic analysis of recovery from neomycin-induced damage. Scanning $(\boldsymbol{a}-\boldsymbol{f})$ and transmission $(\boldsymbol{g}-\boldsymbol{j})$ electron micrographs of cochlear cultures that were incubated in saline for $5 \mathrm{~min}$ $(\boldsymbol{a}, \boldsymbol{d})$ or $1 \mathrm{~mm}$ neomycin for $5 \mathrm{~min}(\boldsymbol{b}, \boldsymbol{e}, \boldsymbol{g}, \boldsymbol{i})$ or $30 \mathrm{~min}(\boldsymbol{c}, \boldsymbol{f}, \boldsymbol{h}, \boldsymbol{j})$, and then either fixed immediately $(\boldsymbol{a}-\boldsymbol{c}, \boldsymbol{g}, \boldsymbol{h})$ or allowed to recover at $37^{\circ} \mathrm{C}$ for $2 \mathrm{~h}$ after neomycin washout $(\boldsymbol{d}-\boldsymbol{f}, \boldsymbol{i}, \boldsymbol{j})$ before fixation. Neomycin-induced blebs seen after $5 \mathrm{~min}(\boldsymbol{b}, \boldsymbol{g})$ and $30 \mathrm{~min}(\boldsymbol{c}$ $\boldsymbol{h})$ of neomycin treatment $(\boldsymbol{b}, \boldsymbol{c}$, arrowheads) are mostly no longer visible $2 \mathrm{~h}$ after neomycin washout $(\boldsymbol{e}, \boldsymbol{i}, \boldsymbol{f}, \boldsymbol{j})$. Scale bars: (in $\boldsymbol{f})$ $\boldsymbol{a}-\boldsymbol{f}, 5 \mu \mathrm{m} ; \boldsymbol{g}-\mathbf{j}, 200 \mathrm{~nm}$.

lated strips of the guinea pig organ of Corti (Shi et al., 2005, 2007). Apical PS exposure and membrane blebbing occur spontaneously in guinea pig hair cells, are promoted by sodium loading and cAMP, and can be blocked by inhibitors of adenylate cyclase or PI-3 kinase, or by brefeldin A. In the mouse, PS exposure and blebbing do not occur spontaneously and cannot be elicited by the adenylate cyclase agonist, forskolin, or by ouabain, an agent likely to cause sodium loading. They can be elicited by brief exposure to neomycin, but neomycin-induced PS externalization and blebbing in the mouse cannot be blocked by the reagents that prevent their spontaneous occurrence in the guinea pig. Some of these differences could be attributable to differences in the developmental ages of the tissues. Endolymphatic levels of $\mathrm{Na}^{+}$are high during early development (Anniko and Wróblewski, 1981, 1986) relative to those in the adult (Bosher and Warren, 1978), and the hair cells in early-postnatal mouse cochlear cultures may be better able to tolerate exposure to $\mathrm{Na}^{+}$. Neomycin may also directly activate processes in mouse hair cells that occur down- stream of sodium loading in the guinea pig hair cells, hence explaining why the inhibitors that are effective in the guinea pig are not in the mouse. Hair cells in cochlear cultures may also become slowly loaded with sodium with time in vitro, and this may explain why high extracellular calcium only elicited PS externalization in cultures that had been maintained for $>1$ $\mathrm{d}$ in vitro.

\section{Neomycin entry through the transducer channel elicits PS externalization}

Aminoglycoside antibiotics are permeant blockers of the mechanotransducer channel of the hair cells (Gale et al., 2001; Marcotti et al., 2005), a channel that is localized toward the tips of the stereocilia (Hudspeth, 1982; Jaramillo and Hudspeth, 1991; Denk et al., 1995; Lumpkin and Hudspeth, 1995). Neomycin entry through this channel may activate PS externalization, first in the hair bundle and then around the perimeter of the apical membrane of the hair cell. The block of neomycin-induced PS externalization after calcium chelation, a procedure that cleaves tip links and blocks transduction (Assad et al., 1991), is consistent with this hypothesis, as is the short delay between the time at which PS appears on the hair bundle and the time at which it appears around the perimeter of the apical membrane of the hair cell. Furthermore, the decrease in neomycin-induced PS externalization caused by ouabain may be attributable to a reduction in the transmembrane potential and a decrease in the electrochemical gradient driving neomycin through the mechanotransducer channel.

\section{Neomycin may activate a \\ lipid scramblase}

Neomycin-induced, apical PS externalization in mouse cochlear hair cells could be attributable to a number of different mechanisms. These include activation of lipid scrambling, inhibition of the aminophospholipid translocase (a flippase) or stimulation of a phospholipid transporter (a floppase). The whole-cell capacitance measurements reveal neomycin induces exocytosis, and the fusion of cytoplasmic vesicles with the apical membrane may account for some of the PS externalization that is seen around the perimeter of the apex of the hair cell. Blebbing and PS externalization can, however, occur independently and neomycin-induced PS externalization first occurs on the surface of the stereocilia, within which membrane vesicles are not present. In the absence of specific reagents, floppase activation and/or flippase inhibition cannot be currently excluded as possible mechanisms for neomycin-induced PS externalization. Flippase inhibition would, however, cause a relatively slow accumulation of PS in the outer leaflet (Zwaal et al., 2005), and the rate at which PS appears on the cell surface suggests scramblase 

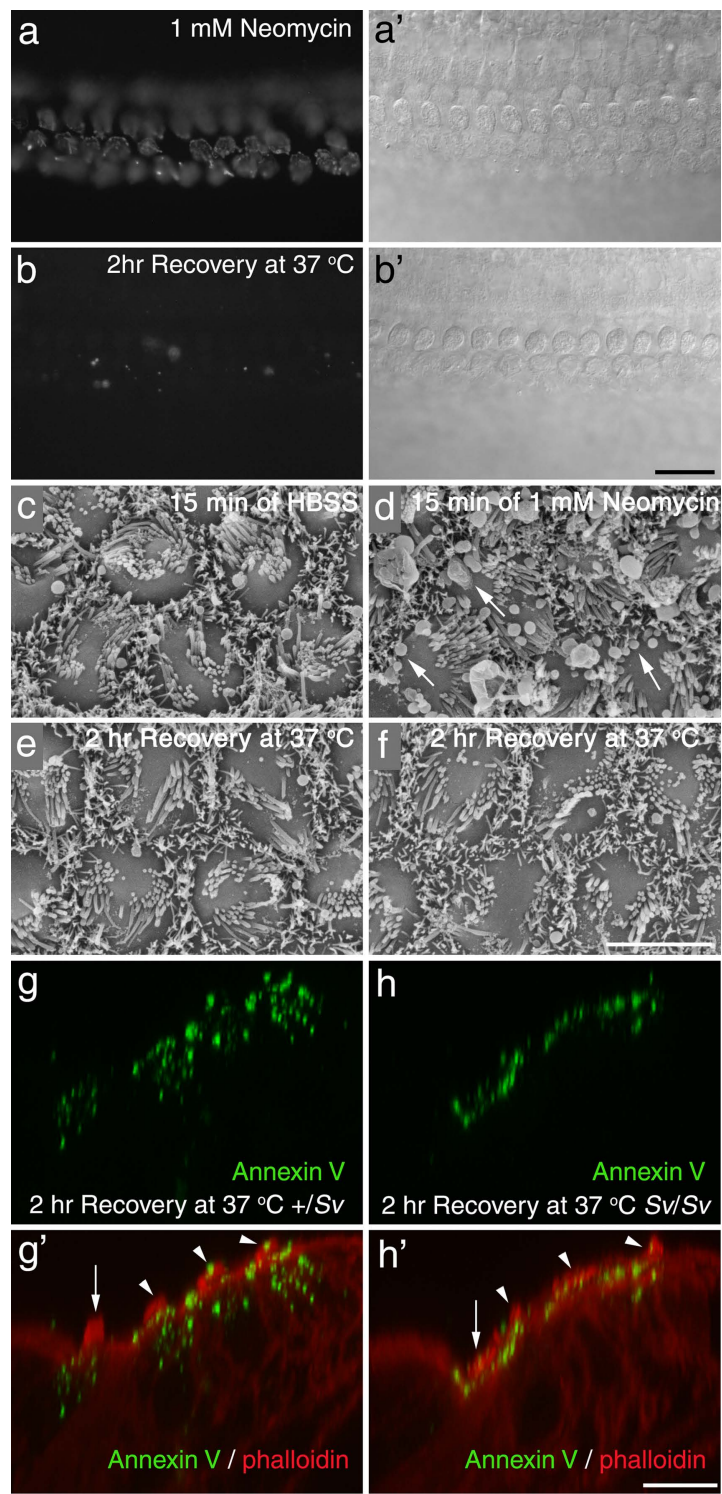

Figure 10. Recovery from neomycin-induced damage in My06 mutants. $\boldsymbol{a}, \boldsymbol{b}$, Fluorescence $(\boldsymbol{a}, \boldsymbol{b})$ and Nomarski interference contrast $\left(\boldsymbol{a}^{\prime}, \boldsymbol{b}^{\prime}\right)$ micrographs of basal-coil cochlear cultures from homozygous $\mathrm{S} v / \mathrm{S} v$ mice that were incubated in $1 \mathrm{~mm}$ neomycin for $15 \mathrm{~min}$, washed in saline, and then incubated in Alexa Fluor 488 annexin V immediately $\left(\boldsymbol{a}, \boldsymbol{a}^{\prime}\right)$ or after a $2 \mathrm{~h}$ recovery period at $37^{\circ} \mathrm{C}\left(\boldsymbol{b}, \boldsymbol{b}^{\prime}\right)$. Images were captured $10 \mathrm{~min}$ after the addition of annexin $\mathrm{V}$. Scale bar: (in $\boldsymbol{b}) \boldsymbol{a}, \boldsymbol{b}, 20 \mu \mathrm{m}$. c-f, Scanning electron micrographs of basal-coil cochlear cultures from homozygous Sv/Sv mice that were incubated in saline $(\boldsymbol{c}, \boldsymbol{e})$ or $1 \mathrm{~mm}$ neomycin $(\boldsymbol{d}, \boldsymbol{f})$ for 15 min, and then fixed immediately $(\boldsymbol{c}, \boldsymbol{d})$ or allowed to recover for $2 \mathrm{~h}$ at $37^{\circ} \mathrm{C}$ before fixation $(\boldsymbol{e}, \boldsymbol{f})$. Scale bar: (in $\boldsymbol{f}$ ) $\mathbf{c}-\boldsymbol{f}, 5 \mu \mathrm{m} . \boldsymbol{g}, \boldsymbol{h}$, Confocal Z-projections of hair cells in basal-coil cochlear cultures from heterozygous $+/ S v(\boldsymbol{g})$ and homozygous $\mathrm{Sv} / \mathrm{Sv}(\boldsymbol{h})$ mice that had been exposed to $1 \mathrm{~mm}$ neomycin in the presence of Alexa Fluor 488 annexin $V$ for $15 \mathrm{~min}$, followed by washout and recovery at $37^{\circ} \mathrm{C}$ for $2 \mathrm{~h}$. The arrows indicate inner hair cells, and the arrowheads indicate outer hair cells. Scale bar: (in $\boldsymbol{h}$ ) $\boldsymbol{g}, \boldsymbol{h}, 10 \mu \mathrm{m}$.

activation as a more likely cause for neomycin-induced PS externalization, at least in the hair bundle.

The erythrocyte lipid scramblase is activated by high levels of intracellular calcium (10-100 $\mu \mathrm{M}$ ) (Woon et al., 1999). It can also be activated by neomycin, poly-L-lysine, or spermine in the absence of $\mathrm{Ca}^{2+}$, and its activation by $\mathrm{Ca}^{2+}$ can be blocked by the PIP2-specific PH domain of PLC $\delta 1$ (Bucki et al., 2000), indicating that PIP2 clustering by $\mathrm{Ca}^{2+}$ or poly-basic compounds may drive scrambling. Lipid scrambling is very rapid, and, in platelets, a complete loss of phospholipid asymmetry can occur within $90 \mathrm{~s}$
(Williamson et al., 1995). PS externalization in mouse hair cells can be induced by neomycin and poly-L-lysine, occurs rapidly (is detectable within $75 \mathrm{~s}$ ), and is reduced in cells overexpressing the $\mathrm{PH}$ domain of PLC $\delta 1 . \mathrm{Ca}^{2+}$ is a permeant blocker of the mechanotransducer channel of the hair cell (Crawford et al., 1991; Lumpkin and Hudspeth, 1995; Lumpkin et al., 1997; Ricci and Fettiplace, 1998), and high levels of extracellular $\mathrm{Ca}^{2+}$ elicit annexin $\mathrm{V}$ labeling in cochlear cultures that have been maintained for $>1 \mathrm{~d}$ in vitro. Although these findings are consistent with neomycin activating lipid scrambling, PS exposure in hair cells could not be elicited by spermine, and both ATP and ionomycin stimulated significant rises in hair cell $\mathrm{Ca}^{2+}{ }_{i}$ without causing PS externalization. Although this latter observation argues against the existence of a $\mathrm{Ca}^{2+}$-activated scramblase in the apical membrane of the hair cell, $\mathrm{Ca}^{2+}{ }_{\mathrm{i}}$ levels in response to ATP or ionomycin may never reach the high micromolar levels required for scramblase activation and the effects of high extracellular $\mathrm{Ca}^{2+}$ may be attributable, in part, to additional interactions with the extracellular face of the membrane. Neomycin and poly-L-lysine may also, to varying extents, interact with the extracellular surface of the hair cells to promote scrambling. Such extracellular interactions may partially explain why not all hair cells are protected from neomycin by pretreatment with calcium chelators.

\section{PS externalization may activate supporting cells}

In many cell types, PS externalization is an early event in apoptosis. It can occur within an hour of activating the extrinsic cell death pathway (Martin et al., 1995) and acts as an "eat-me" signal for engulfment by macrophages (Balasubramanian and Schroit, 2003; Zwaal et al., 2005). In vitro studies of aminoglycosideinduced hair cell death in chick utricle cultures revealed an increase in $\mathrm{Ca}^{2+}{ }_{\mathrm{i}}$ and phosphorylation of c-Jun $\sim 3 \mathrm{~h}$ after onset of neomycin treatment, the release of cytochrome $c$ and caspase- 3 activation by $\sim 12 \mathrm{~h}$, and DNA fragmentation by $\sim 18 \mathrm{~h}$ (Matsui et al., 2004). The apical exposure of PS described here may therefore be one of the earliest events occurring during neomycininduced hair cell death. Whether apical PS externalization occurs in vivo during neomycin treatment remains to be demonstrated. It seems unlikely that it could act as a recognition signal for macrophage engulfment because these cells are not resident in the endolymphatic compartment and have not been reported in this location under pathological conditions. With time, neomycin may reach sufficiently high levels in the cytoplasm to stimulate PS exposure on the basolateral membrane of the hair cells and the subsequent recognition of the dying hair cell by macrophages. In many hair cell epithelia, aminoglycosides can initially cause the selective severing of the apical pole of the hair cell by the supporting cells, cells that have a phagocytic role and engulf much of the debris resulting from hair cell death (Baird et al., 2000; Forge and Li, 2000; Gale et al., 2002). Many of the neomycin-induced hair cell blebs come into contact with microvilli on the surface of adjacent supporting cells (Fig. $2 g$ ), and PS on the surface of these blebs could act as a signal to activate the supporting cells.

\section{Hair cells can repair neomycin-induced damage}

This study also reveals that hair cells have a considerable capacity to repair, and recover from, aminoglycoside-induced apicalsurface damage. After brief neomycin treatment and a short recovery period, PS is no longer detected on the apical surface, apical-membrane blebs disappear, and surface-bound annexin $\mathrm{V}$ is internalized, distributing throughout the supranuclear cytoplasm of the hair cell. No evidence was found for the shedding of membrane blebs, and internalization was temperature depen- 
dent, consistent with it resulting from endocytosis (Weigel and Oka, 1981; Faghihi Shirazi et al., 1982; Tomoda et al., 1989). Large numbers of coated pits are present over much of the apical, nonstereociliary surface of the hair cells in mouse cochlear cultures (Forge and Richardson, 1993), indicating that the subcellular machinery required for endocytosis is present. Surprisingly, although myosin VI has been suggested to play many roles in endocytosis (Hasson, 2003; Buss et al., 2004), especially in polarized epithelial cells (Buss et al., 2001), annexin V internalization and repair from neomycin damage were found to occur in the Snell's waltzer mutant, a mouse that lacks any myosin VI mRNA (Avraham et al., 1995). Although repair from neomycin-induced cell surface damage was observed in the hair cells of homozygous Snell's waltzer mice, particles containing internalized fluorescent annexin $\mathrm{V}$ remained within a zone close to the apical membrane of the hair cells and did not distribute throughout the supranuclear cytoplasm, as they did in the hair cells of heterozygous or wild-type mice. Myosin VI is therefore not required for the removal of neomycin-induced blebs from the apical surface, but it is required for the transport of apically endocytosed material away from the apical pole of the hair cell. This is consistent with previous studies in cell lines that have shown myosin VI transports newly uncoated endocytotic vesicles from the periphery toward the nucleus (Aschenbrenner et al., 2003), and provides the first evidence that myosin VI plays a similar role in the hair cell, a cell type that is critically dependent on this myosin for its survival.

\section{References}

Anniko M, Wróblewski R (1981) Elemental composition of the developing inner ear. Ann Otol Rhinol Laryngol 90:25-32.

Anniko M, Wróblewski R (1986) Ionic environment of cochlear hair cells. Hear Res 22:279-293.

Aschenbrenner L, Lee T, Hasson T (2003) Myo6 facilitates the translocation of endocytotic vesicles from cell peripheries. Mol Biol Cell 14:2728-2743.

Ashmore JF, Ohmori H (1990) Control of intracellular calcium by ATP in isolated outer hair cells of the guinea-pig cochlea. J Physiol 428:109-131.

Assad JA, Shepherd GM, Corey DP (1991) Tip-link integrity and mechanical transduction in vertebrate hair cells. Neuron 7:985-994.

Avraham KB, Hasson T, Steel KP, Kingsley DM, Russell LB, Mooseker MS, Copeland NG, Jenkins NA (1995) The mouse Snell's waltzer deafness gene encodes an unconventional myosin required for the structural integrity of inner ear hair cells. Nat Genet 11:369-375.

Baird RA, Burton MD, Fashena DS, Naeger RA (2000) Hair cell recovery in mitotically blocked cultures of the bullfrog saccule. Proc Natl Acad Sci U S A 97:11722-11729.

Balasubramanian K, Schroit AJ (2003) Aminophospholipid asymmetry: a matter of life and death. Annu Rev Physiol 65:701-734.

Bevers EM, Comfurius P, Dekkers DW, Zwaal RF (1999) Lipid translocation across the plasma membrane of mammalian cells. Biochem Biophys Acta 1439:317-330.

Bosher SK, Warren RL (1978) Very low calcium concentration of cochlear endolymph, an extracellular fluid. Nature 273:377-378.

Bucki R, Giraud F, Sulpice J-C (2000) Phosphatidyl 4,5-bisphophate domain inducers promote phospholipid transverse redistribution in biological membranes. Biochem 39:5838-5844.

Buss F, Arden SD, Lindsay M, Luzio JP, Kendrick-Jones J (2001) Myosin VI isoform localized to clathrin-coated vesicles with a role in clathrinmediated endocytosis. EMBO J 20:3676-3684.

Buss F, Spudich G, Kendrick-Jones J (2004) Myosin VI: cellular functions and motor properties. Annu Rev Cell Dev Biol 20:649-676.

Chen C, Bobbin RP (1998) P2X receptors in cochlear Deiters' cells. Br J Pharmacol 124:337-344.

Crawford AC, Evans MG, Fettiplace R (1991) The actions of calcium on the mechano-electrical transducer current of turtle hair cells. J Physiol 434:369-398.

Denk W, Holt JR, Shepherd GM, Corey DP (1995) Channel imaging of single stereocilia in hair cells: localization of transduction channels at both ends of tip links. Neuron 15:1311-1321.

Dulon D, Moataz R, Mollard P (1993) Characterization of $\mathrm{Ca}^{2+}$ signals generated by extracellular nucleotides in supporting cells of the organ of Corti. Cell Calcium 14:245-254.

Faghihi Shirazi M, Aronson NN Jr, Dean RT (1982) Temperature dependence of certain integrated membrane functions in macrophages. J Cell Sci 57:115-127.

Forge A, Li L (2000) Apoptotic death of hair cells in mammalian vestibular sensory epithelia. Hear Res 139:97-115.

Forge A, Richardson G (1993) Freeze fracture analysis of apical membranes in cochlear cultures: differences between basal and apical-coil outer hair cells and effects of neomycin. J Neurocytol 22:854-867.

Frolenkov GI, Belyantseva IA, Friedman TB, Griffith AJ (2004) Genetic insights into the morphogenesis of inner ear hair cells. Nat Rev Genet 5:489-498.

Gale JE, Marcotti W, Kennedy HJ, Kros CJ, Richardson GP (2001) FM1-43 behaves as a permeant blocker of the hair-cell mechanotransducer channel. J Neurosci 21:7013-7025.

Gale JE, Meyers JR, Periasamy A, Corwin JT (2002) Survival of bundleless hair cells and subsequent bundle replacement in the bullfrog saccule. J Neurobiol 50:81-92.

Gale JE, Piazza V, Ciubotaru CD, Mammano F (2004) A mechanism for sensing noise damage in the inner ear. Curr Biol 14:526-529.

Grati M, Schneider ME, Lipkow K, Strehler EE, Wenthold RJ, Kachar B (2006) Rapid turnover of stereocilia membrane proteins: evidence from the trafficking and mobility of plasma membrane $\mathrm{Ca}^{2+}$-ATPase 2. J Neurosci 26:6386-6395.

Hasson T (2003) Myosin VI: two distinct roles in endocytosis. J Cell Sci 116:3453-3461.

Hasson T, Gillespie PG, Garcia JA, MacDonald RB, Zhao Y, Yee AG, Mooseker MS, Corey DP (1997) Unconventional myosins in inner-ear epithelia. J Cell Biol 137:1287-1307.

Housley GD, Kanjhan R, Raybould NP, Greenwood D, Salih SG, Järlebark L, Burton LD, Setz VC, Cannell MB, Soeller C, Christie DL, Usami S, Matsubara A, Yoshie H, Ryan AF, Thorne PR (1999) Expression of the P2X receptor subunit of the ATP-gated ion channel in the cochlea: implications for sound transduction and auditory neurotransmission. J Neurosci 19:8377-8388.

Hudspeth AJ (1982) Extracellular current flow and the site of mechanotransduction by vertebrate hair cells. J Neurosci 2:1-10.

Jaramillo F, Hudspeth AJ (1991) Localization of the hair cell's transduction channels at the hair bundle's top by iontophoretic application of a channel blocker. Neuron 7:409-420.

Järlebark LE, Housley GD, Thorne PR (2000) Immunohistochemical localization of adenosine 5 '-triphosphate-gated ion channel $\mathrm{P} 2 \mathrm{X}_{2}$ receptor subunits in adult and developing rat cochlea. J Comp Neurol 421:289-301.

Jiang H, Sha SH, Schacht J (2006) Kanamycin alters cytoplasmic and nuclear phosphoinositide signalling in the organ of Corti in vivo. J Neurochem 99:269-276.

Kachar B, Battaglia A, Fex J (1997) Compartmentalized vesicular traffic around the hair cell cuticular plate. Hear Res 107:102-112.

Kotecha B, Richardson GP (1994) Ototoxicity in vitro: effects of neomycin, gentamicin, dihydrostreptomycin, amikacin, spectinomycin, neamine, spermine and poly-L-lysine. Hear Res 73:173-184.

Lagostena L, Mammano F (2001) Intracellular calcium dynamics and membrane conductance changes evoked by Deiters' cell purinoceptor activation in the organ of Corti. Cell Calcium 29:191-198.

Lahne M, Gale JE (2008) Damage-induced activation of ERK1/2 in cochlear supporting cells is a hair cell death-promoting signal that depends on extracellular ATP and calcium. J Neurosci 28:4918-4928.

Lumpkin EA, Hudspeth AJ (1995) Detection of $\mathrm{Ca}^{2+}$ entry through mechanosensitive channels localizes the site of mechanoelectrical transduction in hair cells. Proc Natl Acad Sci U S A 92:10297-10301.

Lumpkin EA, Marquis RE, Hudspeth AJ (1997) The selectivity of the hair cell's mechanoelectrical-transduction channel promotes $\mathrm{Ca}^{2+}$ influx at low $\mathrm{Ca}^{2+}$ concentrations. Proc Natl Acad Sci U S A 94:10997-11002.

Marcotti W, van Netten SM, Kros CJ (2005) The aminoglycoside antibiotic dihydrostreptomycin rapidly enters mouse outer hair cells through the mechano-electrical transducer channels. J Physiol 567:505-521.

Martin SJ, Reutelingsperger CP, McGahon AJ, Rader JA, van Schie RC, 
LaFace DM, Green DR (1995) Early redistribution of plasma membrane phosphatidylserine is a general feature of apoptosis regardless of the initiating stimulus: inhibition by overexpression of Bcl-2 and Abl. J Exp Med 182:1545-1556.

Matsui JI, Gale JE, Warchol ME (2004) Critical events during the aminoglycoside-induced death of sensory hair cells in vitro. J Neurobiol 61:250-266.

Melchionda S, Ahituv N, Bisceglia L, Sobe T, Glaser F, Rabionet R, Arbones ML, Notarangelo A, Di Iorio E, Carella M, Zelante L, Estivill X, Avraham KB, Gasparini P (2001) MYO6, the human homologue of the gene responsible for deafness in Snell's waltzer mice, is mutated in autosomal dominant nonsyndromic hearing loss. Am J Hum Genet 69:635-640.

Meyers JR, MacDonald RB, Duggan A, Lenzi D, Standaert DG, Corwin JT, Corey DP (2003) Lighting up the senses: FM1-43 loading of sensory hair cells through nonselective ion channels. J Neurosci 23:4054-4065.

Petit C (2006) From deafness genes to hearing mechanisms: harmony and counterpoint. Trends Mol Med 12:57-64.

Phillips KR, Tong S, Goodyear R, Richardson GP, Cyr JL (2006) Stereociliary myosin-1c receptors are sensitive to calcium chelation and absent from cadherin 23 mutant mice. J Neurosci 26:10777-10788.

Piazza V, Ciubotaru CD, Gale JE, Mammano F (2007) Purinergic signalling and intercellular $\mathrm{Ca}^{2+}$ wave propagation in the organ of Corti. Cell Calcium 41:77-86.

Ricci AJ, Fettiplace R (1998) Calcium permeation of the turtle hair cell mechanotransducer channel and its relation to the composition of the endolymph. J Physiol 506:159-173.

Richardson GP, Russell IJ (1991) Cochlear cultures as a model system for studying aminoglycoside induced ototoxicity. Hear Res 53:293-311.

Russell IJ, Richardson GP (1987) The morphology and physiology of hair cells in organotypic cultures of the mouse cochlea. Hear Res 31:9-24.
Schacht J (1976) Biochemistry of neomycin ototoxicity. J Acoust Soc Am 59:940-944.

Schacht J (1978) Purification of polyphosphoinositides by chromatography on immobilised neomycin. J Lipid Res 19:1063-1067.

Schacht J (1979) Isolation of an aminoglycoside receptor from guinea pig inner ear tissues and kidney. Arch Otoloaryngol 224:129-134.

Schneider ME, Belyantseva IA, Azevedo RB, Kachar B (2002) Rapid renewal of auditory hair bundles. Nature 418:837-838.

Shi X, Gillespie PG, Nuttall AL (2005) $\mathrm{Na}^{+}$influx triggers bleb formation on inner hair cells. Am J Physiol Cell Physiol 88:C1332-C1341.

Shi X, Gillespie PG, Nuttall AL (2007) Apical phosphatidylserine externalization in auditory hair cells. Mol Membr Biol 24:16-27.

Tomoda H, Kishimoto Y, Lee YC (1989) Temperature effect on endocytosis and exocytosis by rabbit alveolar macrophages. J Biol Chem 264:15445-15450.

Tritsch NX, Yi E, Gale JE, Glowatski E, Berles DE (2007) The origin of spontaneous activity in the developing auditory system. Nature 450:5-55.

Weigel PH, Oka JA (1981) Temperature dependence of endocytosis mediated by the asialoglycoprotein receptor in isolated rat hepatocytes. J Biol Chem 256:2615-2617.

Williamson P, Bevers EM, Smeets EF, Comfurius P, Schlegel RA, Zwaal RFA (1995) Continuous analysis of the mechanism of activated transbilayer movement in platelets. Biochemistry 34:10448-10455.

Woon LA, Holland JW, Kable EP, Roufogalis BD (1999) $\mathrm{Ca}^{2+}$ sensitivity of phospholipid scrambling in human red cell ghosts. Cell Calcium 25:313-320.

Zwaal RF, Comfurius P, Bevers EM (2005) Surface exposure of phosphatidyl serine in pathological cells. Cell Mol Life Sci 62:971-988. 